\title{
Which Monetary Shocks Matter in Small Open Economies? Evidence from SVARs
}

\author{
Jongrim Ha*, Inhwan So**
}

The views expressed herein are those of the authors and do not necessarily reflect the official views of the Bank of Korea or the World Bank Group. When reporting or citing this paper, the authors' names should always be explicitly stated.

\footnotetext{
* Economist, Development Economics Prospects Group (DECPG), World Bank, E-mail: jongrim.ha@gmail.com.
} ** Economist, Economics Research Institute, The Bank of Korea, Tel: +82-2-759-5413, E-mail: ihsoh@bok.or.kr.

The authors are particularly grateful to Eswar S. Prasad, Karel Mertens, G. Andrew Karolyi, Kristoffer P. Nimark, Yu-chin Chen, Fabio Ghironi, and Ji Hyung Lee for their help and support. The authors would also like to thank Jong Ku Kang, Kyounghoon Park, Jin Hyuk Yoo, and other anonymous referees for their valuable suggestions and comments for this paper. 


\section{Contents}

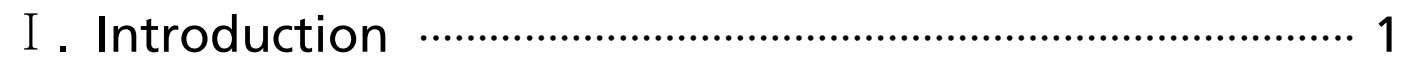

II. Theoretical Motivation and Hypotheses …….............. 5

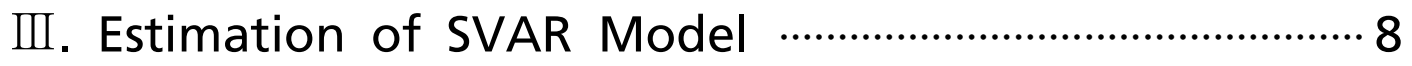

IV. Empirical Analysis Results ……..................................... 17

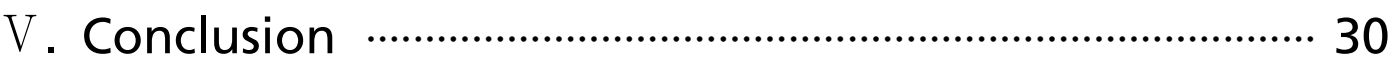

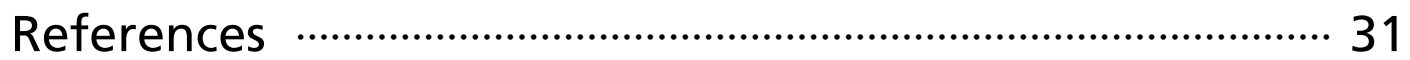

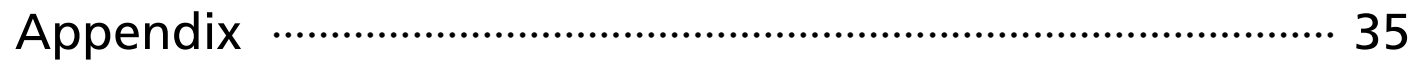




\section{Which Monetary Shocks Matter in Small Open Economies? Evidence from SVARs}

This paper investigates the nature of monetary policy transmission in the U.S. and selected small open economies by estimating SVAR models using the external instrument identification method. Differing from related studies on the U.S., which employ high-frequency futures data on Federal Funds rates, we exploit alternative sets of external instruments for the focal economies. We find that U.S. monetary policy plays an important role in monetary transmission in SOE interest rates, presumably hampering the effectiveness of domestic monetary policy. We also provide some evidence that foreign exchange rates in this process respond to monetary shocks as Dornbusch (1976)'s overshooting hypothesis.

Keywords: Monetary policy transmission, External instrument identification, Structural VAR model

JEL Classification: E44, E52 


\section{I . Introduction}

The frictionless transmission of monetary policy (hereafter 'MP') shocks through financial markets is a key assumption in conventional macroeconomics as well as in practical policy discussions. The central banks in many advanced countries currently choose overnight interest rates as an MP operating instrument, based on the belief that short-term interest rates, among other candidate instruments, are the most directly related to their macroeconomic targets. They attempt to steer inflation and/or output gaps towards targets via market interest rates at all maturities. Transmission of policy effects to other financial market asset prices are, in this sense, a crucial prerequisite for successful MP implementation. 1)

It is, however, yet to be determined whether, in a world of open financial markets, MP decisions transmit through a variety of financial markets effectively and in a timely way. U.S. financial markets, for instance, confronted Greenspan's conundrum in the mid-2000s, during which a global savings glut kept long-term rates low even as the Federal Reserve raised short-term rates. This phenomenon is not confined to the U.S. To the extent that interest rate movements in small open economies (hereafter 'SOEs') are heavily influenced by international monetary and financial spillovers, their movements are more likely to deviate from a central bank's policy stance (Turner (2013), Obstfeld (2015)).2) As a result, central banks are faced with a dilemma in their efforts to achieve macroeconomic stability because focusing only on short-term rates can bias the assessment of a given policy stance.

Existing empirical studies on MP transmission in SOEs nevertheless have paid less attention to transmission through financial markets, focusing mainly on the direct relationship between MP shocks and macroeconomic variables,

1) As we discuss in Chapter 2, conventional models of monetary policy transmission regard financial markets as frictionless, thereby predicting long-term rates which rely entirely on the expected path of short-term rates in reaction to MP actions.

2) South Korea, for example, has experienced such a conundrum, with long-lasting, low levels of long-term rates despite consecutive MP tightening in 2010-11, and this was attributed to the influence of a strong surge in foreign investments into national bond markets. 
typically assuming there are no frictions in capital and financial markets (e.g., Obstfeld et al. (2005), Frankel et al. (2004)). Specifically, few studies explicitly deal with how well market interest rates, e.g., long-term bond yields, respond to local MP shocks, assuming that the traditional interest rate channel performs well as theory predicts. ${ }^{3) 4)}$ Moreover, there is still no conclusive consensus on the dynamic relationship between MP and foreign exchange (FX) rates in the literature. Despite many prior results on the puzzling movements of exchange rates in response to MP shocks, e.g., foreign exchange rate and forward premium puzzles, $\left.{ }^{5}\right)$ several recent studies reconcile the empirical results with theory by adopting new identification strategies.6) Moreover, to the extent that foreign MP shocks play an important role in explaining movements of domestic financial asset prices under financial integration, the transmission mechanism of foreign MP shocks must be equally considered in studies on domestic MP transmission.

Taking these issues into account, we seek to investigate the channels of MP transmission in SOEs within and across borders. To this end, we use an open-economy SVAR model-a main workhorse in the field of empirical MP transmission studies with various financial market variables as well as macroeconomic variables. Identification of structural monetary policy shocks in SVAR can be problematic, however, especially in a model with multiple financial variables, because of simultaneity issues. Most studies in an open-economy setting impose arbitrary relationships on endogenous variables (e.g., a recursive structure or Cholesky restriction), which assume that some structural shock has no simultaneous effect on financial variables, thereby facing difficulties in sorting out the contemporaneous movements of MP shocks, exchange rates,

3) Studies on the U.S. market have progressed well. For instance, seminal studies, including Cochrane and Piazessi (2002) and Gürkaynak et al. (2005), provide evidence that unanticipated MP shocks significantly influence long-term bond yields and other financial asset prices in the U.S. Another group of studies, including Evans and Marshall (1998) and Rudebush et al. (2006), do not, however, find strong evidence of a close relationship, attributing the relationship to other factors, including appetite for risk.

4) As we discuss in Chapter 2, however, the capacity of SOEs to influence movements of long-term rates can be limited in a world of large capital flow across border and financial integration.

5) See Christiano and Eichenbaum (1995) for the puzzles.

6) See Kim and Roubini (2000) and Bjørnland (2009), for example. 
long-term yields, etc. (Faust et al. (2003), Gertler and Karadi (2015)). In addition, identified monetary structural shocks in such a model can be quite different from each other depending on assumptions regarding the identification of such shocks (Rudebush 1998). This may work as a critical limitation when interpreting empirical results pertaining to the dynamic relationship between structural shocks and endogenous variables, e.g., impulse response functions (IRFs) and decomposition of forecast error variances.

The identification scheme proposed by Stock and Watson (2012) and Mertens and Ravn (2013), to which we refer as the external instrument identification scheme, has considerable appeal because it exploits the attractive features of SVARs while addressing the identification issues raised above by using information from external instruments. In the area of MP transmission studies, Gertler and Karadi (2015) combine a SVAR set-up with such an identification scheme, exploiting high-frequency external instrument variables, federal funds, and euro dollar futures rates. Contrary to findings in the literature on U.S. markets, this identification method has not yet been applied to related studies of other economies. One critical reason for this omission may be that there are no futures markets with active trading in such monetary policy operating targets in those countries, and thus external data for MP shocks are not easily obtainable.

Given these circumstances, we contribute to the literature in the following respects. This paper revisits the conventional topic of MP transmission in SOEs, but focuses on how well domestic MP shocks propagate through financial markets and on whether such transmission is distorted by international monetary spillovers. To that end, the SVAR models in this paper explicitly test and compare the impact of domestic as well as foreign (U.S.) MP shocks on multiple market interest rates at a variety of maturities. Furthermore, we test MP transmission in national currency markets, in light of prior theoretical and empirical findings that foreign exchange rates play an important role in domestic and foreign MP transmission in open countries.

In addition, we avoid a simultaneity problem involving MP actions and other macroeconomic or financial variables by identifying monetary shocks using 
external instruments identification instead of making direct arbitrary assumptions about contemporaneous interaction between variables. Specifically, we exploit a variety of high-frequency financial data in the focal SOE countries as well as other measures obtained from econometric methods as external instruments to identify domestic and foreign MP shocks, and we provide a parsimonious characterization of MP shock transmission mechanisms in SOEs. ${ }^{7)}$

Our empirical findings are as follows. First, medium- and long-term interest rates in the SOEs under study respond quite weakly to domestic MP shocks, and these effects are short-lived, which represents a more readily discernible response than estimates for the U.S. suggest. Meanwhile, foreign MP shocks have significant and persistent effects on domestic financial and macroeconomic variables, indicating that MP implementations in our sample SOEs may have been either hampered or strengthened by international monetary spillovers. Considering that overnight and short-term interest rates are monetary policy instruments in SOEs, any significant response of those variables to foreign MP shocks may indicate some sort of policy interdependence among central banks, e.g., policy coordination. Second, foreign exchange rates in this process are seen to respond significantly to MP shocks, as Dornbusch (1976) predicted. Contrary to the findings of existing studies that have reported counter-evidence for the overshooting hypothesis (e.g., Eichenbaum and Evans (1995), Grilli and Roubini (1995), Cushman and Zha (1997)), we find that an increase in policy rates causes the nominal exchange rate to appreciate instantaneously and then to depreciate gradually in line with uncovered interest parity (UIP), with few exceptions. Finally, a group of external instrument variables for the identification are tested and selected, among which movements of overnight spot rates on MP decision dates turn out to be the most suitable instrument for such identifications.

7) Recent studies, including Rogers et al. (2015) and Passary and Rey (2015), adopt a similar identification strategy. This study, however, is differentiated with other related studies in several aspects. We focus, for instance, on the identification of local MP shocks in selected SOEs by testing a variety of economic variables in selected SOEs as instrumental variables for MP shocks. In so doing, we observe IRF results of macroeconomic variables in SOEs following U.S. and local MP shocks and furthermore compare the overall influence of the two structural MP shocks in the dynamic movements of variables in the SOEs. 
The remainder of this paper is organized as follows. In Chapter 2 we provide an overview of theoretical relationships between endogenous variables in the context of open-economy structural models. In Chapter 3 we specify SVAR models and identifying restrictions. Chapter 4 summarizes the empirical results and Chapter 5 concludes.

\section{Theoretical Motivation and Hypotheses}

Standard New-Keynesian models with sticky prices and frictionless financial markets indicate that transmission of MP shocks to credit costs and thus to aggregate spending operates via yield curves assuming price rigidity. Given the expectation hypothesis of the term structure, the effect of MP decisions on the paths of current and expected short-term interest rates is summarized in equation (1):

$$
R_{t}^{m}=m^{-1} E_{t}\left[\sum_{i=0}^{m-1} R_{t+i}\right]+\xi_{t}^{m}
$$

where $R_{t}^{m}$ is an $m$-period zero-coupon government bond yield at time $t, R_{t}$ is a short-term interest rate (e.g., a central bank policy rate), and $\xi_{t}^{m}$ is an $m$-period term premium. The term premium captures additional compensation for the interest rate (duration) risk inherent in medium- or long-term bond positions as well as residual effects of idiosyncratic market factors. If the premium is assumed to be constant over time, changes in the path of short-term policy rates will dominate changes in long-term rates, allowing central banks to influence movements of output and inflation (Gertler and Karadi (2015)).

The extent of a central bank's control, especially in SOEs, over macroeconomic developments is, however, controversial because policy and other monetary shocks migrate from other countries under international financial integration, possibly causing monetary spillovers even when exchange 
rates float freely (Obstfeld (2015)). The international monetary transmission mechanism can be considered as operating with the following, direct and indirect, channels through the short- and long- term yield structure.

In integrated capital markets, a country's manipulation of short-term rates $\left(R_{t}^{*}\right)$, especially if it is a large open economy such as the U.S., inevitably directly affects short-term rates $\left(R_{t}\right)$ in other open countries following the interest-parity relationship represented in (2):

$$
R_{t}=R_{t}^{*}+E_{t} \Delta\left(e_{t}\right)+\rho_{t}
$$

where $e_{t}$ is a nominal FX rate vis-á-vis the U.S. dollar and $\rho_{t}$ is a currency risk premium in open economies at time $t$.

Although changes in the interest rate difference between two countries are absorbed mainly by adjustments in exchange rates, market interest rates in an open country are significantly influenced by foreign MP shocks, depending on the behavior of the exchange rate and the risk premium. If the Federal Reserve cuts its policy rates but SOEs maintain the path of the short-term interest rate constant in response, for instance, the resulting decrease in the foreign short-term rate causes the nominal exchange rate and, accordingly, macroeconomic variables in SOEs, to fluctuate.8) In order to avoid sharp exchange rate movements, SOE central banks are likely to enhance the correlation between the domestic policy rate and the federal fund rate (FFR).

MP actions abroad can also influence domestic market interest rates indirectly through the combination of domestic MP transmission and international spillovers. Equations (1) and (2) are combined to show the linkage between international long-term rates of the form (3):

$$
R_{t}^{m}=R_{t}^{* m}+m^{-1} E_{t}\left[\sum_{i=0}^{m-1}\left(\Delta e_{t+j}+\rho_{t+j}\right)\right]+\xi_{t}^{m}-\xi_{t}^{* m}
$$

8) Dornbusch's (1976) exchange rate overshooting hypothesis predicts that an increase in the interest rate should make the nominal exchange rate appreciate sharply at first and then depreciate. An initial sharp exchange rate adjustment may have a negative effect on the economy. 
where $R_{t}^{m}$ and $\xi_{t}^{m}$ are an $m$-period zero-coupon bond yield and an $m$-period term premium in the U.S. at time $t$, respectively. The other notations are the same as those used in equation (1).

Equation (3) implies that unexpected MP shocks in a foreign country at first adjust movements of market interest rates for a variety of maturities in the country and then lead to the correlated movement of market rates in SOEs as long as the change in the expected exchange rates tends to be slow over time and term premiums are internationally correlated across countries (e.g., Turner (2014), Hellerstein (2011)).9)

Overall, these theoretical channels of international monetary transmission through integrated financial markets indicate that foreign MP adjustment can directly and/or indirectly have a significant impact on the movement of market interest rates in SOEs, and thereby influence the effectiveness of their domestic MP. Our empirical analysis leads to three implications of the MP transmission in SOEs that we can test. First, domestic MP shocks transmit through bond yields of multiple maturities instantaneously, with little response reflected in the term premium, based on the expectation hypothesis. We then investigate the role of U.S. MP shocks, as secondary MP shocks in the focal SOEs, by testing the second and third hypotheses: U.S. MP shocks transmit into overnight rates (MP instruments) in SOEs (direct international transmission), and U.S. MP shocks influence other market interest rates, e.g., medium- and long-term rates in non-U.S. open countries (indirect international transmission).

9) Foreign as well as domestic MP shocks also operate through the term premium and the currency risk premium. For example, consider first the case discussed above, an SOE central bank's effort to mitigate a sharp change in the exchange rate following a U.S. MP contractionary shock. Even when there is no monetary intervention such as synchronizing MP actions, consequential capital flows may occur, and thus affect the term premiums in SOE asset markets. Variations in term premiums on long-term assets caused by capital flow at times offset the impact of changes in short-term rates. In addition, SOE bond and currency risk premiums may fluctuate with changes in U.S. monetary policy. Tighter U.S. MP may, for example, raise perceived risk and uncertainty, which will compress capital inflows and boost risk premiums, thereby leading to potential unintended pro-cyclical dynamics in SOE bond markets (Bruno and Shin (2015)). 


\section{Estimation of SVAR Model}

\section{SVAR modeling}

We assume the economy is described by a structural form equation (4):

$$
A X_{t}=\sum_{i=1}^{p} B_{i} X_{t-i}+\varepsilon_{t}
$$

where $X_{t}$ is an $n \times 1$ vector of macroeconomic and financial variables, $A$ and $B_{i}(\forall i \geq 1)$ are nonsingular coefficient matrices, and $\varepsilon_{t}$ is an $n \times 1$ structural disturbances vector. $\varepsilon_{t}$ is serially uncorrelated and $E\left(\varepsilon_{t} \varepsilon_{t}{ }^{\prime}\right)=I$, an identity matrix. For brevity of notation, the specification in (4) omits constant terms and exogenous variables. By premultiplying the inverse of the $A$ matrix on both sides of the equation, the reduced-form representation is obtained as (5):

$$
X_{t}=\sum_{i=1}^{p} \alpha_{i} X_{t-i}+e_{t}
$$

where $\alpha_{i}=A^{-1} B_{i}$, and $e_{t}$ are the reduced-form residuals. The residuals are related to structural shocks, as seen in (6):

$$
e_{t}=\left[\begin{array}{c}
e_{t}^{p} \\
e_{t}^{q}
\end{array}\right]=S \varepsilon_{t}=\left[S^{p} S^{q}\right]\left[\begin{array}{c}
\varepsilon_{t}^{p} \\
\varepsilon_{t}^{q}
\end{array}\right]
$$

where $S=A^{-1}$. $e_{t}^{p}$ denotes a vector for the residuals of domestic and foreign MP instruments (i.e., $e_{t}^{p}=\left[e_{t}^{M P^{*}} e_{t}^{M P}\right]^{\prime}$ ), and $e_{t}^{q}$ is a vector for the residuals of the other variables, and the analogous definition applies to structural shocks $\varepsilon_{t}^{p}$ and $\varepsilon_{t}^{q} . s^{p}$ and $s^{q}$ denote the columns in matrix $S$ that correspond to the impact structural policy shocks $\varepsilon_{t}^{p}$ and $\varepsilon_{t}^{q}$, on each element of the vector of reduced-form residuals $e_{t}$. The variance-covariance matrix of the reduced-form VAR is $\Sigma=E\left[e_{t} e_{t}{ }^{\prime}\right]=E\left[S S^{\prime}\right]$. 
Next, the Wold representation as a function of the structural shocks is given as (7):

$$
X_{t}=\sum_{j=0}^{\infty} C_{j} S \varepsilon_{t-j}=\sum_{j=0}^{\infty} C_{j} s^{p} \varepsilon_{t-j}^{p}+\sum_{j=0}^{\infty} C_{j} s^{q} \varepsilon_{t-j}^{q}
$$

where $C_{j}$ denotes the coefficients of the structural moving average (MA) form. Accordingly, if the financial variables respond to MP innovations, the IRFs of the $k$-th element of vector $X\left(X_{k}\right)$ to a unit shock of $\varepsilon_{t}^{p}$ at time $t+j$ is obtained by (8):

$$
I R F_{k, j}=\frac{\partial X_{k, t+j}}{\partial \varepsilon_{k, t}^{p}}=C_{k, j} s^{p}
$$

where $C_{k, j}$ is the $k$-th row of $C_{j}$.

Forecast error variance decomposition (FEVD) at time $t+j$ can also be calculated from the structural MA representation by (9):

$$
F E V D_{k, j}=\frac{\operatorname{var}\left(\sum_{l=0}^{j} C_{k, l} s^{p} \varepsilon_{t-l}^{p}\right)}{\operatorname{var}\left(\sum_{l=0}^{j} C_{k, l} e_{t-l}\right)}
$$

\section{Identification scheme in SVAR analyses}

The identification strategy should be deliberately chosen since it considerably affects model specification results, most importantly the identification of structural shocks. ${ }^{10)}$ In the monetary VAR literature, exogenous MP shocks are typically obtained by a surprise component from the regression of a policy rate on suggested explanatory variables, e.g., its lags and/or other financial and

10) Obtaining identified 'exogenous' MP shocks is crucial in monetary VAR analyses because the response of variables to endogenous policy actions cannot distinguish the movement of the economy due to the policy action itself and to the variable that spurred that action. 
macroeconomic variables. Dynamic responses of endogenous variables in the VAR to the identified structural shocks, i.e., IRF and FEVD results, therefore vary depending on the assumptions imposed on relationships between endogenous variables. ${ }^{11)}$

In addition, if identification restrictions are assumed without modeling the relationships between variables correctly, the model may generate biased results. For purposes of ease and convenience, for instance, short-run zero restrictions on the impact matrix are conventionally assumed, which orthogonalize reduced-form disturbances by Cholesky decomposition. In the literature on MP transmission as well, the short-run zero restriction has been widely used on the assumption that MP transmission is occasionally uni-directional, i.e., MP shocks do not affect macroeconomic variables while the latter affect MP decisions, and propagation of MP surprises in the financial market in only one direction, from the short-term to the long-term rate. Such a restriction, however, may be distorting because within a given period policy shifts not only influence financial variables but may also be responding to them. Even if the central bank does not react directly to the movement of financial variables, it may respond to the other correlated variables in the VAR.12) Furthermore, there is a growing body of literature, including Carlstrom et al. (2009), in which findings indicate that MP can influence economic variables simultaneously and that Cholesky identification can distort the results, producing price puzzles or muted responses of inflation and output. ${ }^{13)}$

In order to avoid possible identification problems, an identification strategy

11) In this respect, Rudebusch (1998) criticizes the limitations of applying VAR methodology in MP analyses. He argues that structural MP shocks identified recursively from the VAR may not be similar to the shocks obtained outside the VAR.

12) For instance, the results derived from our model with Cholesky identification show that residual series of most financial variables from the proposed VAR model interact simultaneously. Cross-correlations between short- and long-term rates are very high, as high as 0.4-0.9.

13) Since the 1990s, the Federal Reserve and central banks in other developed countries have increasingly relied on communication to influence market beliefs about the expected paths of policy rates and economic conditions, and in this way MP may have immediate effects on macroeconomic variables. If central banks have more information on the future economic situation, e.g., on aggregate demand and inflation, than the public, an announcement by central banks may change agents' expectations and thereby economic activity. A statement that causes economic agents to expect accommodative future aggregate demand may, for example, lead to a spontaneous increase in current consumption and output. 
should avoid direct assumptions regarding elements of the impact matrix while it produces robust exogenous MP shocks regardless of structural identifying assumptions. In this respect, the identification method proposed by Stock and Watson (2012) and Mertens and Ravn (2013) offers attractive features for measuring the effects of structural shocks because it utilizes an information set pertaining to exogenous shocks that are identified outside the VAR and it does not assume direct restrictions on relationships between variables. Gertler and Karadi (2015), who adopt this approach, show that it can be extended to monetary VAR analyses by exploiting information about external MP shocks from the high frequency instrument to test whether MP and other macroeconomic and financial variables have simultaneous relationships.

\section{External instrument identification scheme}

We recover structural parameters related to domestic and foreign MP shocks by using external instrument identification. The main idea behind this identification scheme is to complement the required restrictions for recovering structural parameters from reduced-form VAR residual covariance and the moment conditions that external instruments can be considered orthogonal to other structural shocks but correlated with MP shocks. This scheme enables us to exploit information contained in external instruments and to avoid arbitrary assumptions about structural parameters. The procedures are summarized as follows.

The relationship between residuals of reduced-form $\operatorname{VAR}\left(e_{t}\right)$ and structural shocks $\left(\varepsilon_{t}\right)$ in equation (6) can be rearranged as (10):

$$
\left[\begin{array}{c}
e_{t}^{p} \\
e_{t}^{q}
\end{array}\right]=\left[\begin{array}{ll}
s_{11} & s_{12} \\
s_{21} & s_{22}
\end{array}\right]\left[\begin{array}{c}
\varepsilon_{t}^{p} \\
\varepsilon_{t}^{q}
\end{array}\right]=\left[\begin{array}{l}
s_{11} \varepsilon_{t}^{p}+s_{12} \varepsilon_{t}^{q} \\
s_{21} \varepsilon_{t}^{p}+s_{22} \varepsilon_{t}^{q}
\end{array}\right]
$$

where $s_{11}$ represents the response of the residuals of the MP instrument to its own shock and $s_{21}$ represents the responses of residual series of the other variables to the structural MP shock. Since we are interested in understanding 
how variables respond to MP shocks, $s_{11}$ and $s_{21}$ are the only two parts of the impact matrix $(S)$ to be identified. Next, VAR residuals $e_{t}^{p}$ and $e_{t}^{q}$ can be expressed by the other reduced-form residuals and structural shocks $\varepsilon_{t}^{p}$ or $\varepsilon_{t}^{q}$ because those are composites of structural shocks, as shown in (11) and (12).

$$
\begin{gathered}
e_{t}^{p}=\eta e_{t}^{p}+C_{1} \varepsilon_{t}^{p} \\
e_{t}^{q}=\theta e_{t}^{p}+C_{2} \varepsilon_{t}^{q}
\end{gathered}
$$

where $\eta=s_{12} s_{22}^{-1}, \theta=s_{21} s_{11}^{-1}, C_{1}=s_{11}-s_{12} s_{22}^{-1} s_{21}$, and $C_{2}=s_{22}-s_{21} s_{11}^{-1} s_{12}$. In particular, the $2 \times 2$ matrix $C_{1}$ represents variance-covariance between two structural MP shocks, and it has the following relationship with $s_{11}$ and $s_{21}$, as shown in (13) and (14). 14)

$$
\begin{gathered}
{\left[\begin{array}{l}
s_{11} \\
s_{21}
\end{array}\right]=\left[\begin{array}{c}
\left(I-s_{12} s_{22}^{-1} s_{21} s_{11}^{-1}\right)^{-1} \\
s_{21} s_{11}^{-1}\left(I-s_{12} s_{22}^{-1} s_{21} s_{11}^{-1}\right)^{-1}
\end{array}\right] C_{1}} \\
C_{1} C_{1}^{\prime}=\left(I-s_{12} s_{22}^{-1} s_{21} s_{11}^{-1}\right) s_{11} s^{\prime}{ }_{11}\left(I-s_{12} s_{22}^{-1} s_{21} s_{11}^{-1}\right)^{\prime}
\end{gathered}
$$

Thus, obtaining $s_{11}$ and $s_{21}$ requires identification of two parts: One is $s_{21} s_{11}^{-1}(=\theta)$, which can be estimated by two-stage least squares (2SLS) estimation, and the others are $s_{11} s^{\prime}{ }_{11}$, and $s_{12} s_{22}^{-1}$, which can be calculated by restrictions from the covariance matrix.

(Restriction from 2SLS estimation: $s_{21} s_{11}^{-1}(=\theta)$ )

Consider first the regression of equation (12). Since the reduced-form residual

14) $C_{1}$ can be rearranged as $C_{1}=s_{11}-s_{12} s_{22}^{-1} s_{21}=\left(I-s_{12} s_{22}^{-1} s_{21} s_{11}^{-1}\right) s_{11}$ and thus $s_{11} C_{1}^{-1}=\left(I-s_{12} s_{22}^{-1} s_{21} s_{11}^{-1}\right)^{-1}$. Similarly, $C_{2}$ can be expressed in terms of partitions of the $S$ matrix as the following form: $s_{21} C_{1}^{-1}=s_{21} s_{11}^{-1} s_{11} C_{1}^{-1}=s_{21} s_{11}^{-1}\left(I-s_{12} s_{22}^{-1} s_{21} s_{11}^{-1}\right)^{-1}$. 
for MP instrument $\left(e_{t}^{p}\left(=s_{11} \varepsilon_{t}^{p}+s_{12} \varepsilon_{t}^{q}\right)\right)$ is correlated with $C_{2} \varepsilon_{t}^{q}$, denoting it as $u_{t}$ hereafter, we can obtain consistent estimates of $\theta$ of regression $e^{q}$ on $e^{p}$ from 2SLS, employing appropriate IVs that satisfy the following moment conditions:

$$
\begin{gathered}
E\left[Z_{t} u_{t}\right]=0 \text { or } E\left[Z_{t} \varepsilon_{t}^{q}\right]=0 \\
E\left[Z_{t} e_{t}^{p}\right]=\pi(\pi \neq 0) \text { or } E\left[Z_{t} \varepsilon_{t}^{p}\right]=\phi(\phi \neq 0)
\end{gathered}
$$

(Restriction from covariance matrix: $s_{11} s^{\prime}{ }_{11}$, and $s_{12} s_{22}^{-1}$ )

In addition to the restrictions derived from IV estimation, identification of $s_{11}$ and $s_{21}$ requires the additional restrictions from the covariance matrix. Consider the following reduced form variance-covariance and its partitioning:

$$
\Sigma=E\left[S S^{\prime}\right] \Rightarrow\left[\begin{array}{ll}
\Sigma_{11} & \Sigma_{12} \\
\Sigma_{21} & \Sigma_{22}
\end{array}\right]=\left[\begin{array}{ll}
s_{11} s^{\prime}{ }_{11}+s_{12} s^{\prime}{ }_{12} & s_{11} s^{\prime}{ }_{21}+s_{12} s^{\prime}{ }_{22} \\
s_{21} s^{\prime}{ }_{11}+s_{22} s^{\prime}{ }_{12} & s_{21} s^{\prime}{ }_{21}+s_{22} s_{22}^{\prime}
\end{array}\right]
$$

Then, $s_{11} s^{\prime}{ }_{11}, s_{12} s_{22}^{-1}$ is obtained by the following closed-form solution:

$$
\begin{gathered}
s_{11} s^{\prime}{ }_{11}=\Sigma_{11}-s_{12} s^{\prime}{ }_{12} \\
s_{12} s_{22}^{-1}=\left(s_{12} s^{\prime}{ }_{12} \theta^{\prime}+\left(\Sigma_{21}-\theta \Sigma_{11}\right)^{\prime}\right)\left(s_{22} s^{\prime}{ }_{22}\right)^{-1}
\end{gathered}
$$

where $s_{12} s^{\prime}{ }_{12}=\left(\Sigma_{21}-\theta \Sigma_{11}\right)^{\prime} Q^{-1}\left(\Sigma_{21}-\theta \Sigma_{11}\right), \quad s_{22} s^{\prime}{ }_{22}=\Sigma_{22}+s_{21} s_{11}^{-1}\left(s_{12} s^{\prime}{ }_{12}-\Sigma_{11}\right)\left(s_{21} s_{11}^{-1}\right)$ and $\left.Q=\Sigma_{22}-\left(\Sigma_{21} \theta^{\prime}+\theta \Sigma_{21}\right)+\theta \Sigma_{11} \theta^{\prime} .15\right)$

15) Consider first the fact that $\Sigma_{21}-\theta \Sigma_{11}=C_{2} s^{\prime}{ }_{12}$ because $\Sigma_{21}-\theta \Sigma_{11}=s_{21} s^{\prime}{ }_{11}+s_{22} s^{\prime}{ }_{12}-s_{21} s_{11}^{-1}\left(s_{11} s^{\prime}{ }_{11}+s_{12} s^{\prime}{ }_{12}\right)$ $=s_{22} s^{\prime}{ }_{12}-s_{21} s_{11}^{-1} s_{12} s_{12}^{\prime}=\left(s_{22}-s_{21} s_{11}^{-1} s_{12}\right) s^{\prime}{ }_{12}$.

The derivation of $s_{12} s_{22}^{-1}$ is straightforward, noticing that $s_{12} s^{\prime}{ }_{22}=s_{12} s^{\prime}{ }_{12} \theta^{\prime}+\left(\Sigma_{21}-\theta \Sigma_{11}\right)^{\prime}$.

$Q=Q^{\prime}$ because $Q$ is symmetric, and it is the same as $u_{t} u_{t}^{\prime}$ or $C_{2} C^{\prime}{ }_{2}$. Using this fact, $s_{12} s^{\prime}{ }_{12}$ can be obtained by the following form: $s_{12} s^{\prime}{ }_{12}=s_{12} C^{\prime}{ }_{2} C^{\prime-1}{ }_{2} C_{2}^{-1} C_{2} s^{\prime}{ }_{12}=s_{12} C^{\prime}{ }_{2} Q^{-1} C_{2} s^{\prime}{ }_{12}=\left(\Sigma_{21}-\theta \Sigma_{11}\right)^{\prime}$ $Q^{-1}\left(\Sigma_{21}-\theta \Sigma_{11}\right)$. And from the covariance matrix, $s_{21} s_{21}^{\prime}=s_{21}\left(s_{11}^{-1} s_{11} s^{\prime}{ }_{11} s_{11}^{-1^{\prime}}\right) s^{\prime}{ }_{21}=\left(s_{21} s_{11}^{-1}\right)$ $\left(\Sigma_{11}-s_{12} s^{\prime}{ }_{12}\right)\left(s_{11}^{-1^{\prime}} s^{\prime}{ }_{21}\right)$. 
These restrictions from 2SLS and VAR residual covariance allow for the identification of $C_{1} C^{\prime}{ }_{1}$ and the covariance of $C_{1} \varepsilon_{t}^{p}$. If structural shocks to domestic MP are uncorrelated with foreign MP shocks and vice versa, $C_{1}$ is a diagonal and can be directly identified up to a sign convention from equation (18).16) However, if we cannot impose zero cross-correlations between structural shocks, we must make an arbitrary assumption regarding how domestic MP shocks respond contemporaneously to unanticipated movements in foreign MP instruments, and vice versa, in order to disentangle the causal effects of shocks on both MP shocks. To the extent that the model considers two countries, the U.S. and an SOE, Cholesky decomposition of $C_{1} C^{\prime}{ }_{1}$, supposing that the foreign MP shock is ordered before the domestic MP shock, permits economically meaningful results in this analysis. Finally, by plugging the identified $C_{1}$ back into equation (13), $s_{11}$ and $s_{21}$ are uniquely pinned down.

\section{Data}

We choose nine monthly (except for Australia, for which it is quarterly) ${ }^{17}$ ) macroeconomic and financial variables in the VAR, reflecting the theoretical set-up described in Chapter 2. In particular, the VAR model comprises logs of the domestic consumer price index ( $P$, 'price' hereafter), logs of seasonally adjusted industrial production ( $Y$, 'output' hereafter), domestic and foreign policy interest rates $\left(M P\right.$ and $\left.M P^{*}\right)$, three-month, three-year, and ten-year government bond yields ( $R 3_{m}, R 3_{y}$, and $\left.R 10_{y}\right)$, bank lending rates (Lend), and logs of the foreign exchange rate against one unit of the U.S. dollar (FX). ${ }^{18)}$ In addition, following procedures employed in prior literature, four external variables are included to isolate exogenous latent factors that may influence

16) If so, a simpler identification approach, such as the one Gertler and Karadi (2015) employ, can be directly applied to identify $s_{11}$ and $s_{21}$.

17) Since Australia reports macroeconomic variables (output, price, etc.) only in the quarterly base, we employ quarterly averages of its financial data.

18) The variables are specified in levels to implicitly determine any potential co-integrating relationship between them; see Hamilton (1994). 
Table 1: List of Variables in SVAR System

\begin{tabular}{|c|c|c|c|c|c|c|}
\hline Variable & Category & U.S. & Australia & Canada & Korea & U.K. \\
\hline$M P^{*}$ & U.S. MP & - & \multicolumn{4}{|c|}{ Effective FFR } \\
\hline$Y$ & Output & \multicolumn{5}{|c|}{ Industrial production (Seasonally Adjusted) } \\
\hline$P$ & Price & \multicolumn{5}{|c|}{ Consumer Price Index } \\
\hline$M P$ & $\begin{array}{l}\text { Overnight } \\
\text { rate }\end{array}$ & $\begin{array}{l}\text { Effective } \\
\text { FFR }\end{array}$ & $\begin{array}{l}\text { Cash } \\
\text { rate }\end{array}$ & $\begin{array}{l}\text { MMF } \\
\text { rate }\end{array}$ & $\begin{array}{l}\text { Call } \\
\text { rate }\end{array}$ & $\begin{array}{c}\text { Bank } \\
\text { rate }\end{array}$ \\
\hline$R 3 m$ & $\begin{array}{l}\text { Short-term } \\
\text { rate }\end{array}$ & \multicolumn{5}{|c|}{ TB (3-month) rate (Korea: CD 91-days rate) } \\
\hline$R 3 y$ & $\begin{array}{l}\text { Medium-term } \\
\text { rate }\end{array}$ & \multicolumn{5}{|c|}{ TB (3-year) rate } \\
\hline R10y & $\begin{array}{l}\text { Long-term } \\
\text { rate }\end{array}$ & \multicolumn{5}{|c|}{ TB (10-year) rate (Korea: TB 5-year rate) } \\
\hline Lend & Lending & \multicolumn{5}{|c|}{$\begin{array}{l}\text { Overall lending rate including loan rates } \\
\text { to households and firms }\end{array}$} \\
\hline$F X$ & FX rate & - & \multicolumn{4}{|c|}{ FX rates per US dollar } \\
\hline \multicolumn{2}{|c|}{ Control Variables } & \multicolumn{5}{|c|}{$\begin{array}{l}\text { Commodity price index, Dummy variable for the period between } \\
\text { August } 2008 \sim \text { June } 2009 \text {, CBOE volatility index, U.S. dollar index }\end{array}$} \\
\hline \multicolumn{2}{|c|}{$\begin{array}{l}\text { Sample periods are L } \\
\text { (1990 2013), U.K. (19 }\end{array}$} & $\begin{array}{l}(1980 \sim 20 \\
2013)\end{array}$ & rea (199 & 13), Cana & (1996 2 & Austra \\
\hline
\end{tabular}

endogenous variables in the VAR system simultaneously: the international commodity price index, a crisis dummy, the CBOE volatility index, and the dollar index (e.g., Kim 2001 and Bjørnland 2009, among many others).

The four focal open countries represent open economies that depend heavily on foreign economies, especially the U.S., from both real economic and financial market perspectives. These countries have employed inflation targeting as an MP regime and used short-term interest rates as an MP operating instrument. Moreover, they are also commonly equipped with well-developed financial markets with sufficient trading volume to validate our use of financial asset prices to identify IVs. And, for the purpose of comparing the empirical results, we also estimate a SVAR model with U.S. data as well as a benchmark. Table 1 summarizes the detailed description of the data. 
Table 2: Instrumental Variables

\begin{tabular}{|c|c|c|c|}
\hline Category & IV & Country & Instruments \\
\hline \multirow{4}{*}{$\begin{array}{l}\text { Short-term } \\
\text { spot rates }\end{array}$} & $\begin{array}{c}\mathrm{IV1} \\
\text { (overnight rates) }\end{array}$ & $\begin{array}{l}\text { AU } \\
\text { CA } \\
\text { KO } \\
\text { UK } \\
\text { US }\end{array}$ & $\begin{array}{l}\text { Overnight cash rates } \\
\text { Overnight MMF rates } \\
\text { Overnight call rates } \\
\text { Average } 4 \text { UK bank's rates } \\
\text { Effective FFR rates }\end{array}$ \\
\hline & $\begin{array}{c}\mathrm{NV} 2 \\
(1-\text { month spot rates })\end{array}$ & $\begin{array}{l}\text { AU } \\
\text { CA } \\
\text { KO } \\
\text { UK } \\
\text { US }\end{array}$ & $\begin{array}{l}\text { Bank bills rates (1-month) } \\
\text { Bank deposit rates (1-month) } \\
\text { TB (1-month) rates } \\
\text { Euro-dollar deposit (1-month) rates }\end{array}$ \\
\hline & $\begin{array}{c}\text { NV3 } \\
\text { (3-month spot rates) }\end{array}$ & $\begin{array}{l}\text { AU } \\
\text { CA } \\
\text { KO } \\
\text { UK } \\
\text { US }\end{array}$ & $\begin{array}{l}\text { Bank bills rates (3-month) } \\
\text { Bank deposit rates (3-month) } \\
\text { CD rates (3-month) } \\
\text { Deposit rates (3-month) } \\
\text { U.S. TB (3-month) yield }\end{array}$ \\
\hline & $\begin{array}{c}\text { IV4 } \\
\text { (FX rates) }\end{array}$ & SOES & FX rates per U.S. dollar \\
\hline
\end{tabular}

Notes: 1) '-' indicates that the IV is not available for a given country.

2) AU: Australia; CA: Canada; KO: Korea; SOEs: the selected four small open economies.

*Panel B: Futures rates and others

\begin{tabular}{|c|c|c|c|}
\hline Category & IV & Country & Instruments \\
\hline \multirow{5}{*}{$\begin{array}{l}\text { Futures rates } \\
\text { under financial } \\
\text { instruments }\end{array}$} & $\begin{array}{c}\mathrm{N} 5 \\
\text { (short-term futures) }\end{array}$ & $\begin{array}{l}\text { AU } \\
\text { CA } \\
\text { KO } \\
\text { UK } \\
\text { US }\end{array}$ & $\begin{array}{l}\text { Futures under } 3 \text {-month rates } \\
- \\
\text { CD rates (3-month) futures } \\
\text { Futures under } 3 \text {-month rates } \\
\text { FFFRs with maturity } 1 \text { month, and } 3 \text { months, } \\
\text { Eurodollar futures rates with } 3 \text { months, } 6 \text { months, } \\
9 \text { months, } 12 \text { months }\end{array}$ \\
\hline & IV6 (medium-term futures) & SOES & Futures under 3-year TB \\
\hline & IV7 (long-term futures) & SOES & Futures under 10-year TB \\
\hline & IV8 (currency futures) & SOEs & Futures under FX rates per USD \\
\hline & IV9 (stock price futures) & SOES & Futures under national stock price index \\
\hline $\mathrm{BN}$ & IV10 (BN) & SOES & BN-decomposed overnight rates \\
\hline TR & IV11 (Taylor rule) & SOES & Estimated Taylor-rule residual \\
\hline
\end{tabular}

Notes: 1) '-' indicates that the IV is not available for a given country.

2) AU: Australia; CA: Canada; KO: Korea; SOEs: the selected four small open economies. 


\subsection{Instrumental variables (IVs)}

Prior studies on U.S. MP use mostly high-frequency movements of Federal Fund futures rates around FOMC meetings as ideal instruments for identifying MP shocks. Other economies, however, are not yet equipped with derivative markets for MP instruments. Given this limitation, we propose various sets of alternative IVs for external instrument identification based on prior theoretical and empirical findings, including short-term spot rates, futures rates under financial instruments, and surprise in overnight rates estimated by statistical method and Taylor rule assumption. See the details in Appendix 1.

IVs tested for focal SOEs and the U.S. are summarized in Table 2. For the U.S., we use IV data proposed by Gertler and Karadi (2015) and Gürkaynak et al (2005), and FFFR changes within a narrow (thirty-minute) window around FOMC meetings. In addition, we test some daily movements of financial instruments for comparison.

\section{Empirical Analysis Results}

\section{IV selection}

To apply external instrument identification, we first turn to the issue of instrument choice in our VAR models. We select suitable instruments in our analysis based on the following conditions:

$$
\begin{array}{ll}
\text { (relevancy) } & \operatorname{rank}\left(E\left[Z_{t} \varepsilon_{t}^{p}\right]\right)=L \\
\text { (orthogonality) } & E\left[Z_{t} \varepsilon_{t}^{q}\right]=0
\end{array}
$$

where $L$ is the number of endogenous variables. In particular, we use the $F$-statistic of the first-stage regression of VAR residual of a particular policy indicator regressed on various instrument sets to test the relevance of IVs. ${ }^{19}$ ) 
Moreover, considering that we choose a combination of multiple IVs, we test the over-identification restriction for selected IVs with each first-stage residual series using Hausman-Sargan (hereafter, 'Sargan') ${ }^{20)}$ statistics. ${ }^{21)}$

In estimating open-economy SVAR models for the selected SOEs, following the test results as well as those of prior studies, including Gertler and Karadi (2015), we use intraday movements of Federal fund futures rates and Eurodollar futures rates for some maturities (IV5a, IV5b, IV5d, IV5e, and IV5f) as IVs for U.S. MP shocks. In addition, as for IVs of SOEs' local MP shocks, we use movements of overnight rates (IV1), overnight-rate surprises estimated by statistical method (IV10), and Taylor rule assumption (IV11), which are found to be most suitable, in terms of relevancy and exogeneity. Those instruments are comparable to the traditional IVs (high frequency FFFR movements) for the US. IV test results for the U.S. and the focal SOEs are summarized in Appendix 2.

\section{Results from SVAR: Impulse response functions (IRFs)}

To show how the MP transmission mechanism works in the focal SOEs, we first present the IRFs of interest rates at various maturities for domestic MP innovation. Contrary to conventional theory, the increase in long-term interest rates following monetary tightening proved to be much smaller and more short-lived than those of short-term rates. We then show how the interest rates responded to U.S. MP shocks to address the other central question of this paper: namely, how foreign MP shocks influence domestic interest rates, directly or indirectly. In response to surprise foreign MP tightening moves,

19) A weak instruments problem is generally tested by the $F$-statistic of the first-stage regression residual regressed on instruments, which must be greater than ten for the bias in the estimators to be less than $10 \%$, according to Staiger and Stock (1997). However, the $F$-statistic above ten may not ensure the unbiased estimators if heteroskedasticity and autocorrelation exist in the regression, as argued by Olea and Pflueger (2013). This paper determines the presence of weak instruments based on the $F$-statistic following Gertler and Karadi (2015), considering the fact that economic structure and monetary policy regime of focal countries have not changed during the analysis period.

20) We can test for endogeneity of the IVs using Sargan statistics only if we have more IVs than potentially endogenous explanatory variables (over-identification).

21) If the Sargan statistic, which follows $\chi^{2}$ distribution, is statistically different from zero, then some of the instruments used for estimation are not exogenous. 
interest rates at all maturities exhibit significant and persistent increases of several basis points. We also find that nominal exchange rates respond to monetary policy shocks in line with the overshooting hypothesis in this process, contrary to findings in the existing literature, which report the exchange rate puzzle or delayed overshooting (e.g., Cushman and Zha (1997)).

\subsection{Effects of MP shocks on the interest rates22)}

When a domestic MP shock occurs, market interest rate responses weaken with longer maturity, contrary to what the conventional New Keynesian framework predicts. The first column in Figure 1 displays the effect of a contractionary MP shock on short-term interest rates, with the shock normalized to an initial one-percentage-point increase, while the second and third columns show the corresponding effects on medium- and long-term bond yields, respectively. Clearly, short-term rates respond spontaneously to the shock, increasing one to two percentage points at a maximum. However, medium- and long-term bond yields respond much more weakly and these responses are shorter-lived than those of short-term rates. Especially in Canada, market rates do not seem to react significantly to an MP-tightening shock, even showing negative movement in the early stages of such shocks. The above-reported empirical results indicate that domestic MP does not propagate sufficiently and quickly enough from short-term rates to medium- or long-term rates. To shed light on this aspect of MP, Figure 2 displays the responses of interest rate spreads to a contractionary MP shock of (1\%). Compared with the benchmark (U.S.) case, the responses of spreads between medium- or long-term rates and short-term rates in the focal SOEs are distinctively shorter. Considering the characteristics of SOEs, the above disturbance in the MP transmission mechanism may more or less result from the influence of international monetary and financial spillovers, such as the flow of global

22) U.S. MP shocks may have impact on policy rates of SOEs due to several reasons like policy coordination. However, it should be considered that endogenous changes in policy rates are not identified separately in an impulse response analysis. 
Figure 1: Response of Interest Rates to a 1\% Domestic MP Shock
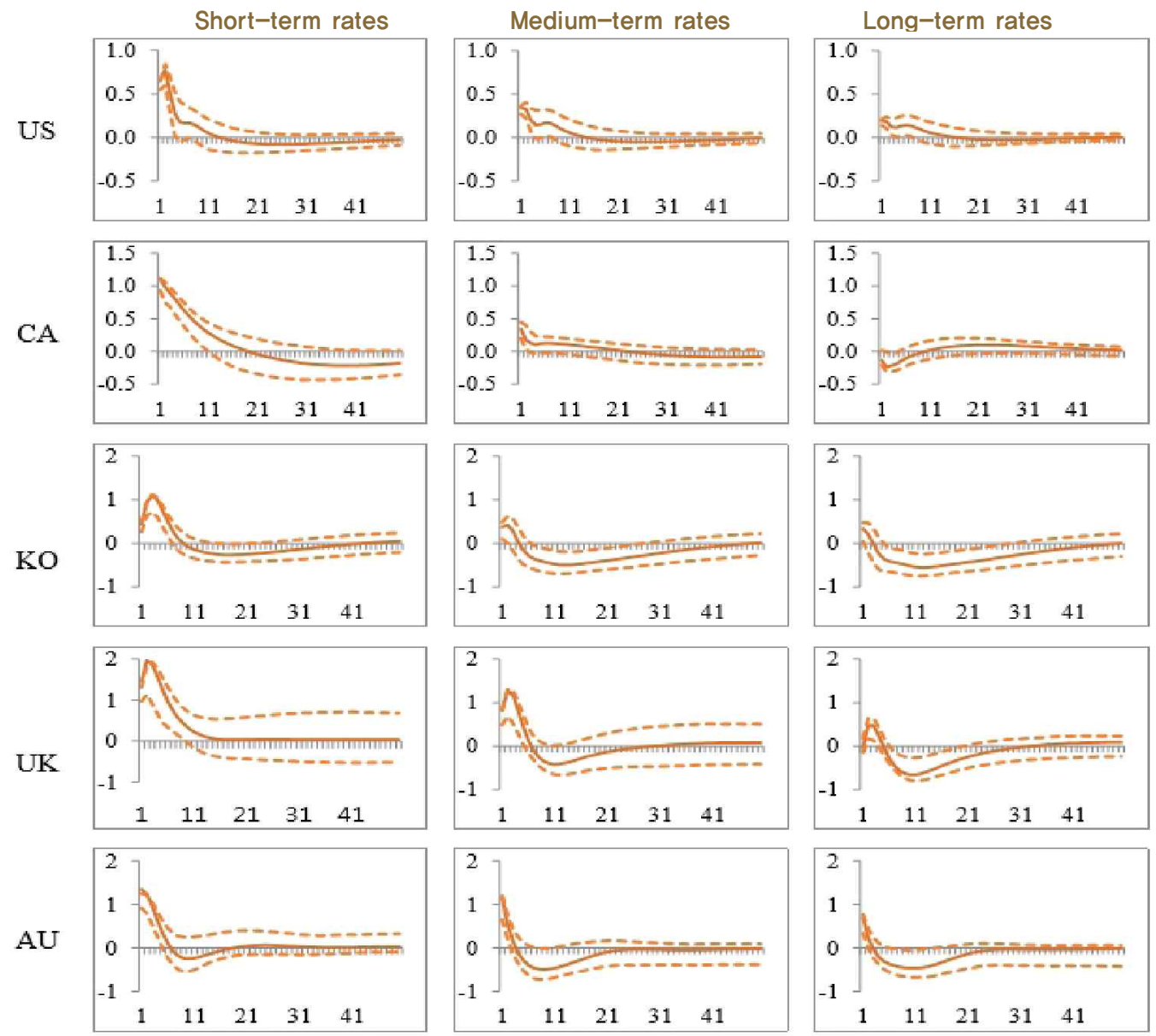

Notes: 1) The $Y$ axis indicates \%.

2) The $X$ axis indicates month(s) for the U.S., Canada (CA), Korea (KO), and the U.K. and quarter(s) for Australia (AU).

3) Broken lines are the 16th and 84th quantiles of the empirical distribution of IRFs based on 5,000 draws.

Figure 2: Response of Interest Rates Spreads to a 1\% Domestic MP Shock

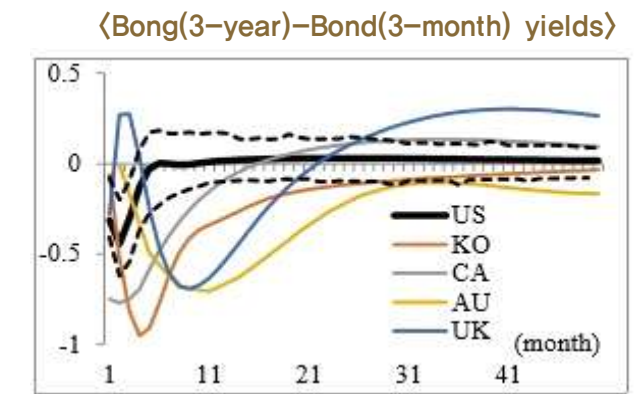

〈Bong(10-year)-Bond(3-month) yields〉

Note: Black broken lines are the 16th and 84th quantiles of the empirical distribution based on 5,000 draws for the U.S.

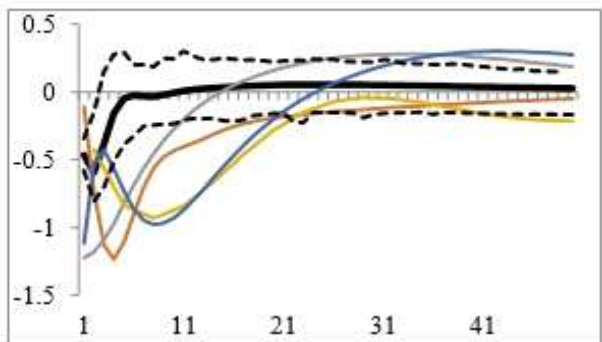


Figure 3: Response of SOE Interest Rates to a 1\% U.S. MP Shock
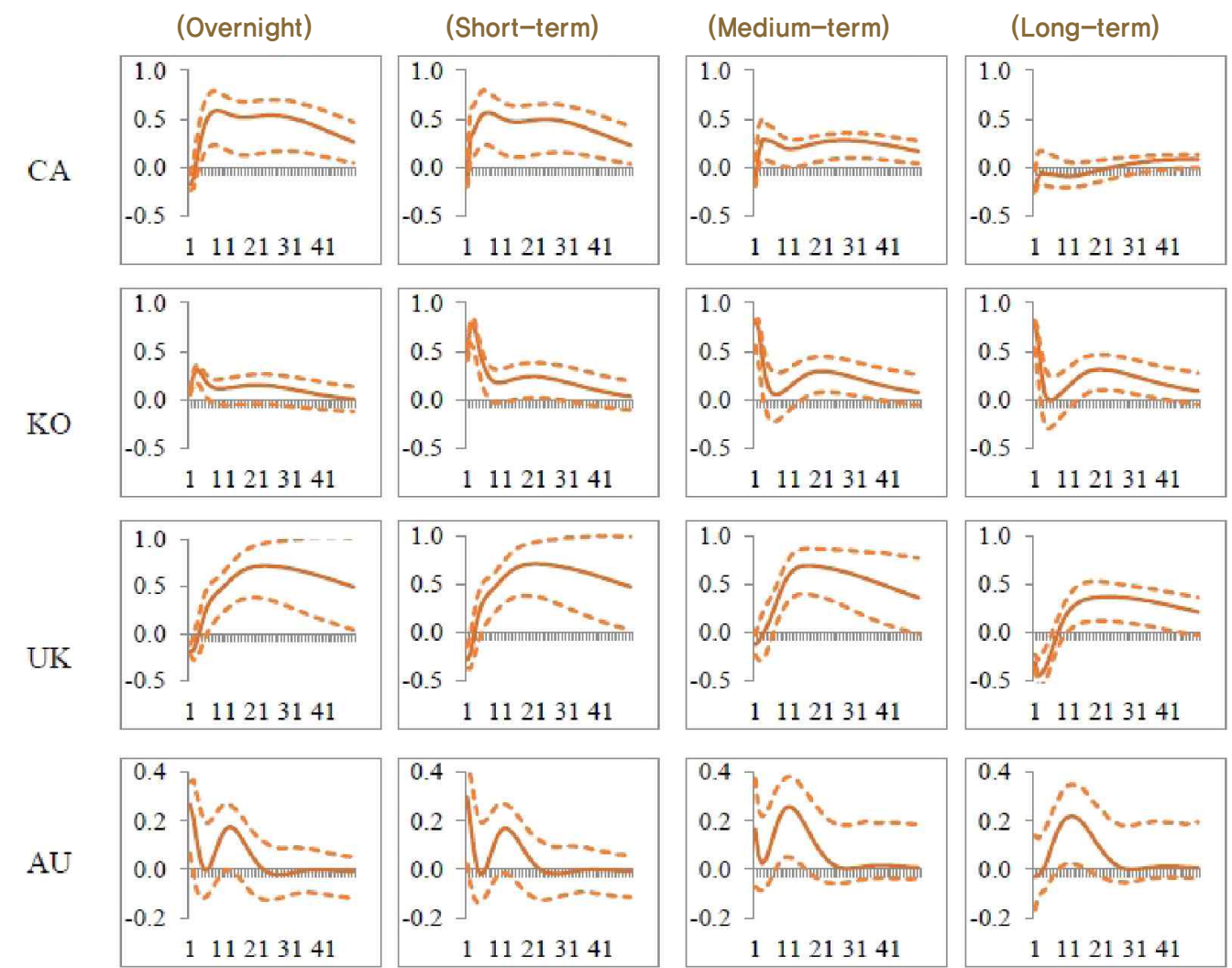

Notes: 1) The $Y$ axis indicates \%.

2) The $X$ axis indicates month(s) for the U.S., Canada (CA), Korea (KO), and the U.K. and quarter(s) for Australia (AU).

3) Broken lines are the 16th and 84th quantiles of the empirical distribution of IRFs based on 5,000 draws.

liquidity or movements of the exchange rate caused by changes in domestic or foreign MP stances.

To infer further details of the transmission mechanism for MP shocks, we examine the effects of U.S. MP shocks on market interest rates in each focal country. In Figure 3, market rates show positive and persistent responses to a contractionary U.S. MP shock. Overall, two results stand out concerning our hypotheses that test international monetary transmissions. First, overnight and short-term interest rates in the focal SOEs show significantly positive responses of up to $1 \%$ to the shock in most non-U.S. countries. One possible interpretation of this result is that contractionary U.S. MP shocks lead to international 
synchronization of MP, or of the corresponding market expectations, which helps absorb the impact of a dramatic change in the exchange rate that applies to direct cross-border monetary transmission. This synchronization of monetary policies may be explained by the monetary coordination between the U.S. and other SOEs. As a monetary transmission from the U.S. takes place, the shock comes to reflect the policy stance of the country through which it passes. ${ }^{23)}$

Second, we also investigate the reactions of longer-term yields to examine the indirect channel of foreign MP transmission. Medium- and long-term rates react to foreign MP shocks similarly to short-term rates; in the UK and Canada the shock has negative effects at first but the confidence intervals suggest that these initial reactions are not significantly different from zero. Combining our findings of the linkage between U.S. MP shocks and U.S. market rates and prior results in the literature, which have documented significant co-movements among long-term bond yields in multiple countries (e.g., Ehrmann et al., 2011), this result may indicate that U.S. MP shocks also transmit indirectly to domestic long-term bond markets through the linkage between the U.S. and the focal SOE long-term bond markets (indirect cross-border monetary transmission).

To illustrate the characteristics of the IRFs of each MP shock, Figure 4 compares the influence of domestic and foreign MP shocks on market interest rates in each country. This confirms our conclusion that foreign MP shocks seem to have weaker but much more persistent effects on the focal SOEs' market interest rates.

The above-reported results contradict the findings of previous studies such as Kim (2001), who suggests that non-U.S. G-6 countries do not react strongly to U.S. MP by documenting that negative U.S. FFR innovations do not lead to a significant and substantial decrease in non-U.S. short-term interest rates. However, those past studies may be limited significantly in their ability to isolate exogenous U.S. MP shocks. In particular, their identified MP structural shocks depend largely on the questionable assumption of a simultaneous relationship between the variables. After identifying the shocks based on external

23) Many studies have discussed the potential benefits between large economies and SOEs, both theoretically and empirically. See, for instance, Frankel and Roubini (2001) or Taylor (2013). 
Figure 4: Response of Domestic Interest Rates to $1 \%$ Domestic and U.S MP Shocks
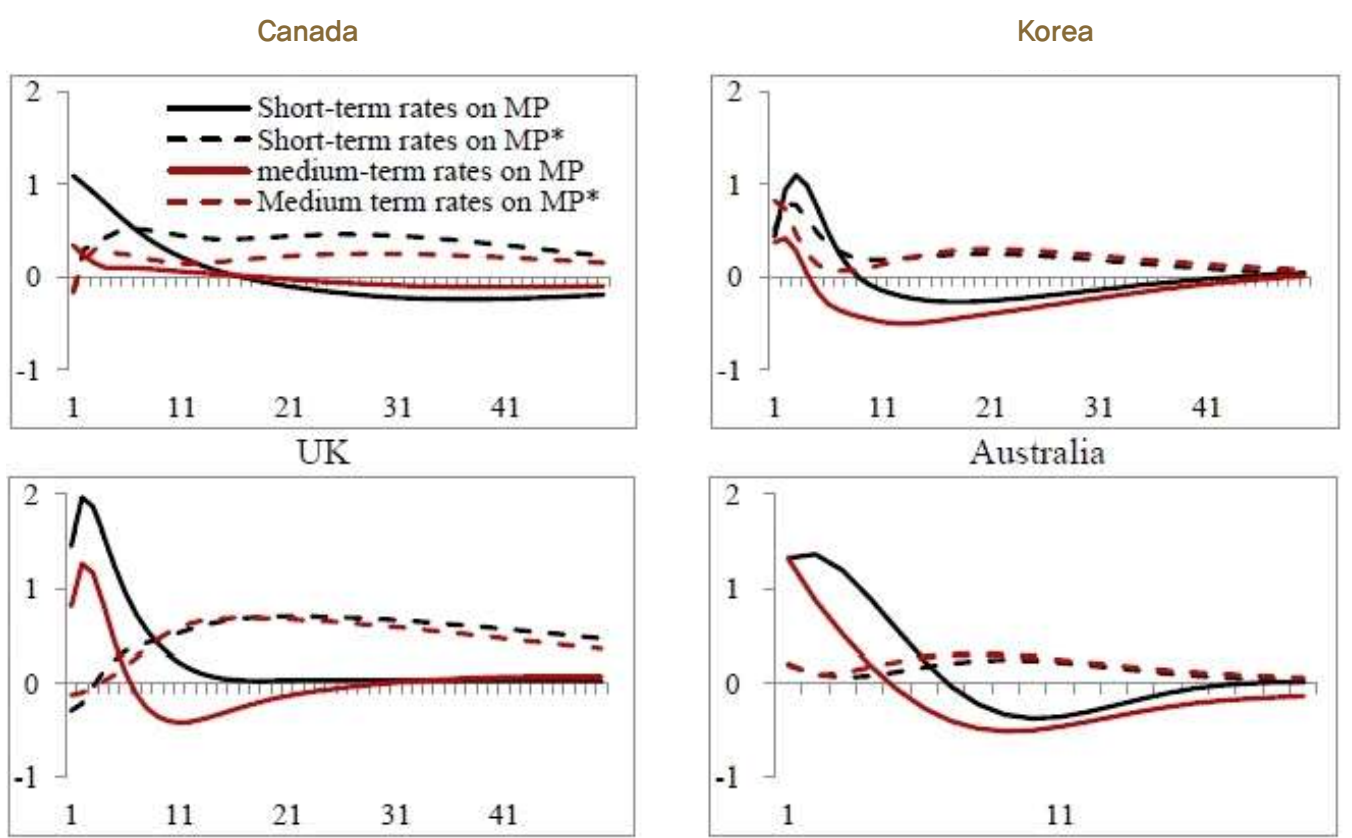

Note: $\mathrm{Y}$ axis indicates $\%$ and $\mathrm{X}$ axis is month(s) for Canada, Korea, and the U.K., and quarter(s) for Australia.

information outside the VAR framework, we conclude that the endogenous reaction of focal SOE MP and interest rates to U.S. MP surprises is substantial and lasts longer than domestic shocks, consistently with what Faust et al. (2003), who study the U.K. and Germany cases, find.

\subsection{Effects of MP shocks on the nominal foreign exchange rates}

Turning now to consider the effect of MP shocks on the exchange rate, there is no evidence of a puzzle, which is consistent with the overshooting hypothesis of Dornbusch (1976). This is surprising insofar as most empirical VAR studies that have reported that, on a contractionary MP shock, the exchange rate either depreciates (this is the exchange rate puzzle; see Grilli and Roubini, 1995; Sims, 1992), or, appreciates for a prolonged period of up to three years, thereby violating the UIP condition (delayed overshooting; see Eichenbaum and Evans (1995) and Cushman and Zha (1997)). 
Figure 5: Response of FX Rates to a 1\% Domestic and U.S. MP Shock

(FX to MP)
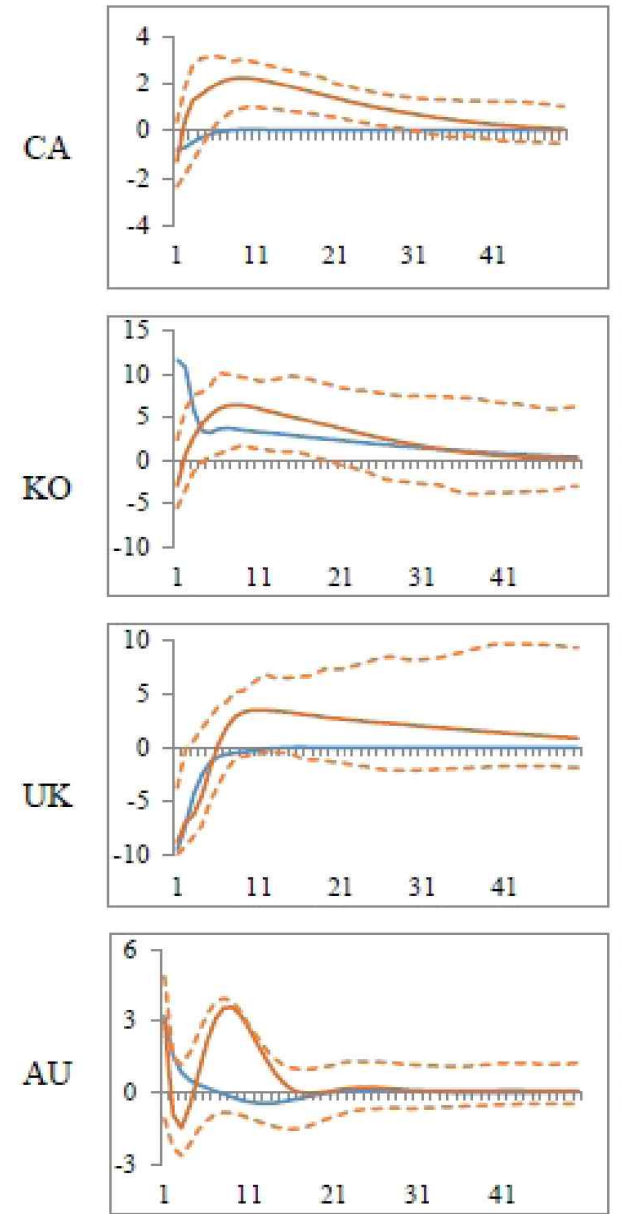

(FX to $\mathrm{MP}^{*}$ )
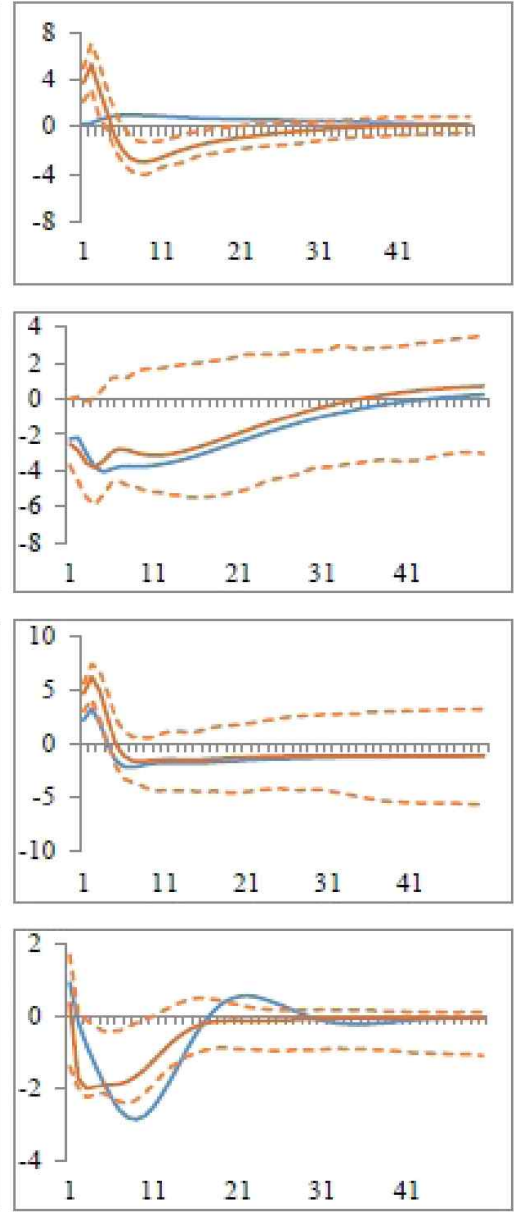

Notes: 1) The $Y$ axis indicates $\%$.

2) The $X$ axis indicates month(s) for Canada (CA), Korea (KO), and the U.K. and quarter(s) for Australia (AU).

3) Broken lines are the 16th and 84th quantiles of the empirical distribution of IRFs based on 5,000 draws.

4) Orange lines indicate estimated IRFs with new identification and blue lines indicate the results with Cholesky identification.

In particular, as shown in the first columns of Figure 5, the initial appreciation of the focal SOE currencies following a contractionary monetary shock is not followed by long and persistent appreciation, as found in previous studies. Except for Australia, which shows a puzzling response (a drop) after the initial appreciation, 24$)$ the exchange rates start to depreciate (rise) gradually after a 
Figure 6: Response of Macroeconomic Variables to a 1\% Domestic and U.S. MP Shock

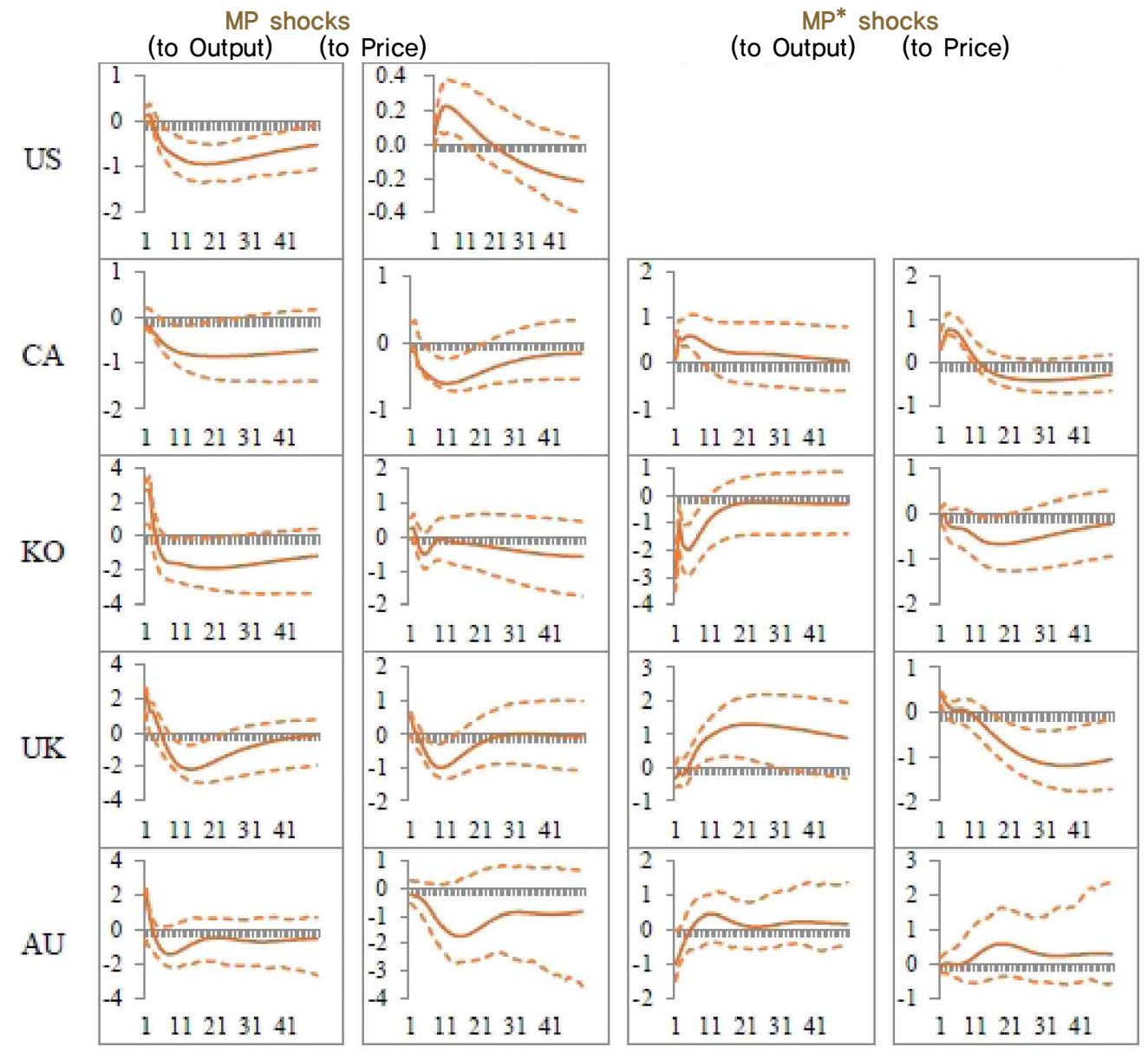

Notes: 1) The $Y$ axis indicates \%.

2) The $X$ axis indicates month(s) for the U.S., Canada (CA), Korea (KO), and the U.K. and quarter(s) for Australia (AU).

3) Broken lines are the 16th and 84th quantiles of the empirical distribution of IRFs based on 5,000 draws.

few quarters. The confidence intervals obtained from bootstrap method also indicate that there is no significant, persistent appreciation while the exchange rates do not depreciate promptly following the impact appreciation. Meanwhile,

24) One possible explanation of this is that, as compared with the other focal countries, the Australian economy as a major commodity-exporting country has become less dependent on the US while the impact of the export activity of other trading partners, such as China and the EU, has strengthened more over the period. 
in response to U.S. MP tightening, the currencies of the focal SOEs appreciate gradually, thus depreciating the US dollar, followed by initial depreciation in line with the overshooting hypothesis (except in Korea, whose currency appreciates without initial depreciation). Such a response is quite consistent with previous IRF results regarding domestic MP shocks. In line with several studies (e.g., Bjørnland (2009), Kim and Roubini (2000), Cushman and Zha (1997)), this result suggests that the inappropriate identification of MP shocks may account for the puzzles observed in the prior literature.25)

\subsection{Effects of MP shocks on the macroeconomic variables}

Finally, it is also important to verify whether output and price react to MP shocks as expected given available theories, because we cannot say that our identified structural shocks are valid if any puzzles in their responses persist. In all countries, output and the price levels decline smoothly over a given horizon following monetary contraction, consistently with conventional theory. The output of the focal SOEs decreases by one to two percent maximum after 1-2 years, and the effect on prices is also negative and reaches a minimum after $1-1.5$ years.

Another notable finding is that the macroeconomic variables show a positive simultaneous response to the shock, although the response is in some cases not statistically significant. This is quite at odds with the conventional belief that MP transmission is a long and complicated mechanism and thereby has uncertain time lags for feasible effects on macroeconomic variables to manifest. We can explain this by noting that MP decisions can significantly influence market expectations regarding future economic situations. Central banks have been influencing market expectations by forward guidance since the 1990s, and in this channel MP may have an immediate effect on macroeconomic variables

25) For comparison purpose, we compare IRFs from Cholesky restrictions with ordering as $\left[M P^{*}, Y, P, F X\right.$, $M P, R 3_{m}, R 3_{y}, R 10_{y}$,Lend] in Figure 5. Contrary to the results drawn from the external instrument identification scheme, the responses of exchange rate produce puzzles under the Cholesky scheme as do previous studies. 
under the belief that central banks have better information regarding future economic situations through earlier access to data or superior economic analysis, and thus statements by central banks somehow reveal private information pertaining to future paths of economic activities and inflation. The direction that responses of macroeconomic variables to news of expectation shocks takes may depend on which news regarding future economic situations is disseminated.26)

The responses of focal SOE outputs to U.S. MP shocks are mixed. Korea shows a significant negative impact of contractionary shocks, while the other focal SOEs respond positively but less significantly. Meanwhile, the responses of prices to U.S. MP shocks are persistently negative with a time lag, except in Australia. This result may be explained by an import price decrease due to appreciation of the domestic exchange rate relative to the U.S. dollar and a decrease in domestic aggregate demand.

\section{Forecast error variance decomposition (FEVD) results}

How much do foreign MP shocks affect the overall variability in the process of domestic MP transmission? To shed some light on this issue, as shown in Table 3, we quantify the contributions of each MP shock to the variance in market interest rates on the impact for the first four years.27)

On a short-run forecast horizon, domestic MP shocks seem to have greater influence on market interest rates than foreign MP shocks, but this relationship reverses on the longer-run horizon; the effect of domestic shocks fade quickly while that of foreign shocks decreases (or even increases in some cases) gradually. In particular, domestic MP shocks explain from $10 \%$ to $30 \%$ of the variation in focal SOE market interest rates (based on a long-run forecast horizon). Domestic shocks have greater explanatory power for short-term and bank lending rates than for medium- or long-term rates. The effect of foreign

26) If economic agents believe, for example, that an MP decision to tighten a central bank's supply of money is based on future accommodative economic activities, outputs will respond positively to the shock.

27) Note that only the columns related to MP shocks, i.e., the first and fourth columns of the $S$ matrix, are identified, so we can quantify the contribution of only domestic and foreign MP shocks. 
Table 3: Contribution of Domestic and U.S. MP Shocks to Market Rate Variation

\begin{tabular}{|c|c|c|c|c|c|c|c|c|}
\hline \multirow{2}{*}{ Forecast horizon (month) } & \multicolumn{2}{|c|}{ Canada } & \multicolumn{2}{|c|}{ Korea } & \multicolumn{2}{|c|}{ UK } & \multicolumn{2}{|c|}{ Australia } \\
\hline & $\mathrm{MP}^{*}$ & $\mathrm{MP}$ & MP* & MP & MP* & $\mathrm{MP}$ & $\mathrm{MP}^{*}$ & MP \\
\hline \multicolumn{9}{|c|}{ (Short-term interest rates) } \\
\hline 1 & 0.7 & 39.0 & 17.5 & 6.9 & 6.6 & 63.2 & 5.1 & 68.5 \\
\hline 12 & 5.6 & 16.0 & 15.7 & 13.8 & 7.5 & 25.6 & 7.0 & 33.2 \\
\hline 24 & 6.9 & 10.2 & 14.4 & 11.7 & 18.3 & 14.4 & 7.9 & 32.3 \\
\hline 48 & 10.2 & 10.1 & 13.2 & 9.7 & 24.8 & 8.9 & 7.8 & 32.0 \\
\hline \multicolumn{9}{|c|}{ (Medium-term interest rates) } \\
\hline 1 & 0.3 & 2.5 & 14.5 & 1.6 & 0.6 & 10.0 & 2.6 & 29.9 \\
\hline 12 & 2.6 & 1.6 & 5.5 & 3.0 & 6.8 & 8.8 & 9.9 & 18.0 \\
\hline 24 & 3.9 & 1.3 & 7.2 & 5.9 & 19.9 & 6.3 & 11.1 & 18.7 \\
\hline 48 & 7.0 & 1.9 & 8.3 & 6.0 & 27.0 & 4.4 & 11.1 & 18.7 \\
\hline \multicolumn{9}{|c|}{ (Long-term interest rates) } \\
\hline 1 & 1.1 & 0.5 & 11.7 & 1.0 & 4.7 & 0.0 & 0.0 & 19.8 \\
\hline 12 & 0.6 & 1.1 & 3.7 & 3.5 & 6.7 & 7.8 & 6.2 & 12.0 \\
\hline 24 & 0.8 & 1.4 & 5.9 & 6.8 & 13.4 & 9.6 & 7.4 & 13.9 \\
\hline 48 & 1.0 & 1.6 & 7.3 & 6.9 & 21.6 & 8.0 & 7.4 & 14.0 \\
\hline \multicolumn{9}{|c|}{ (Bank lending rates) } \\
\hline 1 & 1.4 & 59.7 & 6.7 & 2.0 & 0.5 & 20.9 & 5.8 & 62.4 \\
\hline 12 & 5.3 & 20.6 & 12.0 & 14.7 & 5.0 & 25.3 & 8.1 & 34.3 \\
\hline 24 & 6.7 & 12.3 & 13.5 & 12.7 & 20.2 & 19.3 & 9.0 & 33.1 \\
\hline 48 & 10.2 & 11.8 & 13.0 & 9.8 & 27.8 & 14.7 & 9.0 & 32.7 \\
\hline
\end{tabular}

(U.S.) MP also explains a substantial portion of market interest rate movements. In particular, the contribution of foreign MP shocks to the variation in mediumand long-term rates is greater than that of domestic MP.

Of the four focal open countries, Australia displays a relatively greater share of domestic MP effects on medium- and long-term rates compared with those of foreign MP shocks. But foreign MP shocks also play a nonnegligible role in explaining variations in market rates. In Canada and the U.K., the variation in short-and medium-term rates is affected mainly by foreign MP.28) For long-term rates, foreign MP shocks are still important for explaining the variation in rates in the U.K., but not in Canada. In Korea, U.S. MP shocks play a slightly stronger role in explaining market rates than domestic MP.

28) These results are overall consistent with Cushman and Zha (1997), who found a weak role of domestic MP shocks and strong impacts of foreign factors. 
Table 4: Contribution of Domestic and U.S. MP Shocks to Macroeconomic Variables

$(\%)$

\begin{tabular}{|c|c|c|c|c|c|c|c|c|}
\hline \multirow{2}{*}{ Forecast horizon (month) } & \multicolumn{2}{|c|}{ Canada } & \multicolumn{2}{|c|}{ Korea } & \multicolumn{2}{|c|}{ UK } & \multicolumn{2}{|c|}{ Australia } \\
\hline & $M P^{*}$ & $\mathrm{MP}$ & $\mathrm{MP}^{*}$ & MP & $\mathrm{MP}^{*}$ & MP & $M P^{*}$ & $\mathrm{MP}$ \\
\hline \multicolumn{9}{|c|}{ (Industrial Production) } \\
\hline 1 & 1.5 & 0.0 & 6.7 & 2.6 & 0.1 & 4.2 & 10.9 & 13.0 \\
\hline 12 & 4.8 & 2.0 & 5.6 & 2.8 & 2.1 & 4.8 & 7.2 & 13.1 \\
\hline 24 & 3.2 & 3.5 & 4.3 & 4.6 & 7.0 & 7.8 & 6.3 & 10.8 \\
\hline 48 & 2.4 & 4.5 & 3.3 & 5.9 & 12.3 & 7.0 & 6.6 & 9.5 \\
\hline \multicolumn{9}{|c|}{ (Consumer price index) } \\
\hline 1 & 4.8 & 0.4 & 0.1 & 0.4 & 1.8 & 1.2 & 0.1 & 2.3 \\
\hline 12 & 12.9 & 3.8 & 1.6 & 0.4 & 0.6 & 4.7 & 3.3 & 3.0 \\
\hline 24 & 7.5 & 4.5 & 3.5 & 0.4 & 6.3 & 3.7 & 5.9 & 6.0 \\
\hline 48 & 5.1 & 2.8 & 3.5 & 1.1 & 20.8 & 1.9 & 6.8 & 6.6 \\
\hline \multicolumn{9}{|c|}{ (Foreign exchange rates) } \\
\hline 1 & 7.1 & 1.1 & 2.3 & 1.6 & 10.5 & 14.1 & 0.2 & 4.1 \\
\hline 12 & 15.3 & 8.0 & 6.5 & 9.6 & 10.5 & 9.2 & 17.6 & 11.9 \\
\hline 24 & 16.3 & 12.3 & 7.1 & 11.1 & 9.2 & 9.4 & 17.6 & 12.0 \\
\hline 48 & 15.4 & 12.7 & 6.4 & 10.4 & 9.5 & 9.3 & 17.6 & 12.0 \\
\hline
\end{tabular}

These results emphasize that the short-term rates respond systematically to domestic monetary surprises, but on the long-run horizon they react more strongly to foreign MP shocks. However, domestic monetary shocks do not play an important role in explaining the variation in longer-term bond yields in the focal SOEs, while the other factors, including U.S. MP shocks, do.

Table 4 exhibits FEVD results for macroeconomic variables (output, prices, and exchange rates). Consistently with the FEVD results for market interest rates, U.S. MP shocks show substantial influence on movements of the focal SOE macroeconomic variables as well. The two MP shocks, in sum, account for $5 \%$ to $20 \%$ of the forecast error regarding the output and price variables of the focal SOEs, among which the U.K. shows the greatest impact of U.S. MP shocks. Around $20 \%$ to $30 \%$ of the movement in the exchange rates of the focal SOEs is explained by the domestic and foreign MP shocks in all the countries. 


\section{Conclusion}

This paper revisits the conventional topic of MP transmission in SOEs, but focuses on how easily MP shocks propagate through financial markets and on whether such transmission is hampered by international monetary spillover. To that end, the SVAR model in this paper explicitly tests the impact of domestic and foreign MP shocks, as proxied by U.S. MP shocks, on multiple financial variables including market interest rates at a variety of maturities, which other studies implicitly assume to be ideally strong. Furthermore, this paper tests MP transmission in national currency markets in light of the findings in the literature that foreign monetary shocks and exchange rates play an important role in MP transmission in open countries.

The study's empirical findings are threefold. First, responses to MP shocks of medium- and long-term interest rates in the focal SOEs are weak and sluggish, discernibly more so than estimates for the U.S., while foreign MP shocks have statistically significant and persistent impacts on domestic financial and macroeconomic variables. Second, foreign exchange rates are seen to respond significantly to MP shocks, consistently with Dornbusch's (1976) prediction. Finally, a group of external instrument variables for the identification are tested and selected, among which IVs, movements of overnight spot rates on MP decision dates, turn out to be the most suitable instrument for identification.

The empirical results indicate that market interest rates do not always react in the way that central banks intend. Other structural shocks, most likely external shocks, may lead them to diverge from domestic MP and thereby attenuate the effects of domestic MP. In our analysis, movements of domestic variables are indeed substantially influenced by foreign MP shocks. FEVD results, which show a non-negligible contribution of foreign MP shocks to the variation in medium-and long-term rates, also support this idea. Recalling the conundrum that occurred in the U.S. during the 1990s and 2000s, and the vulnerability of the focal SOEs' financial markets to external factors, the empirical results in this paper may serve to warn central banks that MP implementations in the focal SOEs may be hampered by external influences. 


\section{References}

Beveridge, S., and C. R. Nelson (1981), "A New Approach to Decomposition of Economic Time Series into Permanent and Transitory Components with Particular Attention to Measurement of the Business Cycle," Journal of Monetary Economics, Vol. 7(2), pp. 151-174.

Bjørnland, H. C. (2009), "Monetary Policy and Exchange Rate Overshooting: Dornbusch was Right after All," Journal of International Economics, Vol. 79(1), pp. 64-77.

Bruno, V., and H. S. Shin (2015), "Capital Flows and the Risk-taking Channel of Monetary Policy," Journal of Monetary Economics, Vol. 71, pp. 119-132.

Carlstrom, C. T., T. S. Fuerst, and M. Paustian (2009), "Monetary Policy Shocks, Choleski Identification, and DNK Models," Journal of Monetary Economics, Vol. 56(7), pp. 1014-1021.

Clarida, R., J. Gali, and M. Gertler (2000), "Monetary Policy Rules and Macroeconomic Stability: Evidence and Some Theory," Quarterly Journal of Economics, Vol. 115(1), pp. 147-180.

Cochrane, J. H., and M. Piazzesi (2002), "The Fed and Interest Rates - a Highfrequency Identication," American Economic Review, Vol. 92(2), pp. 90-95.

Cushman, D. O., and T. Zha (1997), "Identifying Monetary Policy in a Small Open Economy under Flexible Exchange Rates," Journal of Monetary Economics, Vol. 39(3), pp. 433-448.

Dornbush, R. (1976), "Expectations and Exchange Rate Dynamics," Journal of Political Economy, Vol. 84(6), pp. 1161-1176.

Ehrmann, M., M. Fratzscher, and R. Rigobon (2011), "Stocks, Bonds, Money Markets and Exchange Rates: Measuring International Financial Transmission," Journal of Applied Econometrics, Vol. 26(6), pp. 948-974.

Evans, C. L., and D. A. Marshall (1998), "Monetary Policy and the Term Structure of Nominal Interest Rates: Evidence and Theory," Carnegie-Rochester Conference Series on Public Policy 49, pp. 53-111. 
Eichenbaum, M., and C. Evans (1995), "Some Empirical Evidence on the Effects of Shocks to Monetary Policy on Exchange Rates," Quarterly Journal of Economics, Vol. 110(4), pp. 975-1009.

Faust, J., J. H. Rogers, E. Swanson, and J. H. Wright (2003), "Identifying the Effects of Monetary Policy Shocks on Exchange Rates Using High Frequency Data," Journal of the European Economic Association, Vol. 1(5), pp. 1031-1057.

Frankel, J. A., and N. Roubini (2001), "The Role of Industrial Country Policies in Emerging Market Crises," National Bureau of Economic Research, w8634.

Gertler, M. L., and P. Karadi (2015), "Monetary Policy Surprises, Credit Costs and Economic Activity," American Economic Journal: Marcroeconomics, Vol. 7(1), pp. 44-76.

Gürkaynak, R. S., B. P. Sack, and E. T. Swanson (2005), "Do Actions Speak Louder than Words? the Response of Asset Prices to Monetary Policy Actions and Statements," International Journal of Central Banking, Vol. 1(1), pp. 55-93.

Hellerstein, R. (2011), "Global Bond Risk Premiums," Staff Reports, Federal Reserve Bank of New York, 499.

Hamilton, J. D. (1994), “Time Series Analysis,” Princeton University Press.

Kim, S. (2001), "International Transmission of U.S. Monetary Policy Shocks: Evidence from VAR's," Journal of Monetary Economics, Vol. 48(2), pp. 339-372.

Kim, S., and N. Roubini (2000), "Exchange Rate Anomalies in the Industrial Countries: a Solution with a Structural VAR Approach," Journal of Monetary Economics, Vol. 45(3), pp. 561-586.

Mertens, K., and M. O. Ravn (2013), "The Dynamic Effects of Personal and Corporate Income Tax Changes in the United States," American Economic Review, Vol. 103(4), pp. 1212-1247. 
Morley, J. (2002), "A State Space Approach to Calculating the Beveridge-Nelson Decomposition," Economics Letters, Vol. 75(1), pp. 123-127.

Mishkin, F. S. (1995), "Symposium on the Monetary Transmission Mechanism," Journal of Economic perspective, Vol. 9(4), pp. 3-10.

Obsfeld, M. (2015), "Trilemmas and Tradeoffs: Living with Financial Globalization,“ Manuscript.

Olea, J. L. M., and C. Pflueger (2013), "A Robust Test for Weak Instruments," Journal of Business \& Economic Statistics, Vol. 31(3), pp. 358-369.

Passari, E., and H. Rey (2015), "Financial Flows and the International Monetary System," The Economic Journal, Vol. 125(584), pp. 675-698.

Rogers, J. H., C. Scotti, and J. H. Wright (2015), "Unconventional Monetary Policy and International Risk Premia," Federal Reserve Board Working Paper.

Rudebusch, G. D. (1998), "Do Measures of Monetary Policy in a VAR Make Sense?" International Economic Review, Vol. 39(4), pp. 943-948.

Rudebush, G. D., E. D. Swanson, and T. Wu (2006), "The Bond Yield 'Conundrum' from a Macro-finance Perspective,' Federal Reserve Bank of San Francisco Working Paper Series, 2006-16.

Sims, C. A. (1980), "Macroeconomics and Reality," Econometrica, Vol. 48(1), pp. 1-48.

Staiger, D., and J. H. Stock (1997), "Instrumental Variables Regression with Weak Instruments," Econometrica, Vol. 65(3), pp. 557-586.

Stock, J. H., and M. W. Watson (2012), "Disentangling the Channels of the 2007-09 Recession," Brookings Papers on Economic Activity, 2012(1), pp. 81-135.

Swanson, E. T. (2015), "Measuring the Effects of Unconventional Monetary Policy on Asset Prices," NBER Working Papers, w21816.

Taylor, J. B. (2013), "International Monetary Policy Coordination: Past, Present and Future," Manuscript. 
Turner, P. (2013), "Benign Neglect of the Long-term Interest Rate," BIS Working Papers, 403.

Turner, P. (2014), "The Long-term Interest Rate, Financial Risks and Policy Choices in EMEs," BIS Working Papers, 441. 


\section{Appendix 1: IV Candidates for MP Shocks}

\section{Daily short-term spot rate changes on MP decision dates: IV 1 through 4}

Following Cochrane and Piazessi (2002) and others, we test daily movements of short-term interest rates around MP decision announcements, by defining an MP shock as the daily change in the spot rates on that day. Financial market participants anticipate MP decisions before actual policy announcements, and short-term rates may have already been adjusted beforehand. If on the contrary the MP announcement is a mere surprise, market rates will adjust only after the announcements. We test the following four short-term interest rates: overnight rates (IV1), market interest rates with maturity of 1 month (IV2), Treasury bill rates with maturity of 3 months (IV3), and daily exchange rates per U.S. dollar (IV4).

\section{Daily futures prices of financial instruments on MP decision dates: IV 5 through 9}

A variety of futures assets, even though the underlying instrument is not directly related to MP, exist in financially developed SOEs. Like spot rates, futures prices also retain meaningful information about market expectations regarding future paths of MP. We test here the following five futures contracts under financial assets: futures prices under short-term (IV5), medium-term (IV6), and long-term (IV7) fixed-income (bond) instruments, ${ }^{29)}$ currency futures rates per USD (IV8), and national stock price futures rates (IV9). 30)31)

29) Although the relationship with the MP instrument is not as close as those with short-term instruments, there are also good reasons to regard movements of futures prices under long-term fixed-income instruments as embedding market expectations for MP announcements. If we follow the expectation hypothesis regarding the term structure, long-term rates can be explained by expectations for short-term rates and the liquidity premium, assuming there is no credit risk with the financial instruments.

30) Theoretical and empirical studies have suggested a relationship between currency or equity prices and MP surprises. For example, a representative theory of the relationship between MP and currency would be the uncovered interest rate parity (UIP) theory. According to UIP, risk-neutral investors are indifferent between the interest rates in two countries since the exchange rate between those countries is expected to be adjusted such that the return on deposits in each country equalizes, thereby eliminating the potential for uncovered interest arbitrage profits. However, as is well-known in international macroeconomics, many 


\section{Beveridge-Nelson decomposed overnight rates: IV10}

If there is no other economic news except MP announcements on MP decision dates, we may define MP shocks as deviations of MP instruments on that day from the expected future paths. What is an 'expected future path'? Here we use an econometric technique of Beveridge and Nelson (1981) ('BN' hereafter) and seek to provide potential instruments for unexpected MP shocks.

Following BN, we define the mean-adjusted permanent component of an I(1) series with drift as its limiting forecast for the infinite time-horizon, as shown in (20).

$$
\begin{aligned}
x_{t}=r_{t}-z_{t} & =r_{t}+\psi^{*}(L) e_{t}=r_{t}+\psi_{0}^{*} e_{t}+\psi_{1}^{*} e_{t-1}+\ldots \\
& =r_{t}+\sum_{j=1}^{\infty} E\left(\Delta r_{t+j}-\mu \mid I_{t}\right)=\lim _{j \rightarrow \infty} r_{t+j \mid t}-\mu j
\end{aligned}
$$

where $x_{t}$ is the (adjusted) permanent component of $r_{t}$ and $z_{t}$ is the transitory component. According to the Box-Jenkins's method, we find that daily MP instruments in each country follow the ARIMA process, as reported in (21).

$$
\begin{aligned}
& \mathrm{US}[\operatorname{ARIMA}(1,1,2)]: \Delta r_{t}=\underset{(25.41)}{0.58 \Delta_{t-1}}+e_{t} \underset{(-32.00)}{0.77 e_{t-1}} \underset{(-4.30)}{0.06 e_{t-2}} \\
& \operatorname{AU}[\operatorname{ARIMA}(2,1,2)]: \Delta r_{t}=0.61 \Delta r_{t-1}-0.95 \Delta r_{t-2}+e_{t}-0.61 e_{t-1}+0.92 e_{t-2} \\
& \text { (47.64) (-64.98) (-38.33) } \\
& \text { CA }[\operatorname{ARIMA}(1,1,0)]: \Delta r_{t}=-0.17 \Delta r_{t-1}+e_{t} \\
& (-11.67) \\
& \mathrm{KO}[\operatorname{ARIMA}(1,1,2)]: \Delta r_{t}=\underset{(25.41)}{0.58} \Delta r_{t-1}+e_{t}-\underset{(-32.00)}{0.77} e_{t-1}-\underset{(-4.30)}{0.06} e_{t-2} \\
& \mathrm{UK}[\operatorname{ARIMA}(1,1,0)]: \Delta r_{t}=\underset{(4.96)}{0.05} \Delta r_{t-1}+e_{t}
\end{aligned}
$$

empirical studies report that high-interest-rate currencies tend to appreciate (the UIP puzzle). Therefore, we need to use these carefully.

31) Following Gertler and Karadi (2015), because the day of an FOMC meeting varies from month to month, we take the following step in constructing daily MP instruments. First, for each day of the month, we cumulate the surprise on any FOMC days during the last 31 days; and second, we create cumulative daily surprise series by cumulating all MP decision-day surprises. 
where $\Delta r_{t}$ is the first difference of the overnight rate, $e_{t}$ is the residual, and the numbers in parenthesis are $t$-values. Following Morley (2002), we can transform this result into a state-space representation, $R_{t}=F R_{t-1}+\varepsilon_{t}$, and implement BN decomposition. For example, for the US case, state space representation can be expressed as (22):

$$
\left[\begin{array}{c}
\Delta r_{t} \\
e_{t} \\
e_{t-1}
\end{array}\right]=\left[\begin{array}{ccc}
\phi_{1} & \theta_{1} & \theta_{2} \\
0 & 0 & 0 \\
0 & 1 & 0
\end{array}\right]\left[\begin{array}{c}
\Delta r_{t-1} \\
e_{t-1} \\
e_{t-2}
\end{array}\right]+\left[\begin{array}{c}
e_{t} \\
e_{t} \\
0
\end{array}\right]
$$

Then, the $\mathrm{BN}$ trend is $r_{t}+(1,1)$ element of $F(I(n)-F)^{-1} R_{1}$ where $n$ denotes a dimension of the state-space matrix, and the transitory component, an MP shock, is the $(1,1)$ element of $-F(I(n)-F)^{-1} R_{t}$. Assuming that there is no economic news on an MP decision day and that overnight financial markets behave consistently with the market efficiency hypothesis, the $\mathrm{BN}$ trend on an MP decision date is the market participants' long-run forecast conditional on information up to the date, and the transitory component on the day is the unexpected MP shock. ${ }^{32)}$

\section{Residuals from forward-looking Taylor-rule estimation: IV 11}

Following Clarida et al. (2000) and many others, we estimate the forwardlooking Taylor rule as equation (23) assuming that the policy rate adjusts to gaps between expected inflation and output and their respective target levels. Residuals from the policy rule estimation can be interpreted as the difference between actual policy rates and the rates implied by the rule had monetary authorities followed it. Roughly speaking, the residuals indicate the unintended policy shocks caused by a central bank that strictly obeys the rule.

$$
r_{t}=\rho r_{t-1}+(1-\rho)\left[r r^{*}+(\beta-1) \pi^{*}+\beta \pi_{t, k}+\gamma x_{t, q}\right]+v_{t}
$$

32) We assume market efficiency in the overnight interest rate market, so the market price may be determined based on the entire information set available up to time $t\left(I_{t}\right)$. 
Table 5: Estimation Results for Forward-looking Policy Rule

\begin{tabular}{cccccc} 
& $\beta$ & $\gamma$ & $\rho$ & $\pi^{*}$ \\
US [1980 2013] & 3.46 & 0.44 & 0.90 & 4.08 \\
& $(0.55)$ & $(0.56)$ & $(0.03)$ & $(0.27)$ \\
\hline \multirow{2}{*}{ CA [1982 2013] } & 3.63 & -0.64 & 0.57 & 2.58 \\
& $(0.40)$ & $(0.64)$ & $(0.13)$ & $(0.16)$ \\
\hline AU [1991 2013] & 3.24 & -2.68 & 0.83 & 2.60 \\
& $(0.56)$ & $(0.71)$ & $(0.03)$ & $(0.17)$ \\
\hline KO [1996 2013] & 1.77 & -0.21 & 0.85 & 4.60 \\
UK [1989 2013] & $(0.51)$ & $(0.17)$ & $(0.02)$ & $(1.12)$ \\
\hline \multirow{2}{*}{ (19) } & 1.84 & 1.13 & 0.44 & 0.68 \\
\end{tabular}

Note: Numbers in parentheses are standard errors.

where $r^{*}, \pi_{t, k}, x_{t, q}, \rho$ are the target interest rate, the inflation rate at time $t+k$, the output gap in period $t+q, 33)$ and the degree of smoothing of interest rate changes, respectively. The real rate and its long-run equilibrium are $r r_{t}^{*} \equiv r_{t}^{*}-E\left[\pi_{t, k} \mid \Omega_{t}\right]$ and $r r_{t}^{*} \equiv r_{t}^{*}-\pi^{*}$, where $\Omega_{t}$ is the information set at the time that the interest rate is set. Note that the residual from the rule is the form $v_{t}=-(1-\rho)\left[\beta\left[\pi_{t, k}-E\left(\pi_{t, k} \mid \Omega_{t}\right)\right]+\gamma\left[x_{t, q}-E\left(x_{t, q} \mid \Omega_{t}\right)\right]\right]$.

Unless $\pi_{t, k}=E\left[\pi_{t, k} \mid \Omega_{t}\right]$ and $x_{t, q}=E\left[x_{t, q} \mid \Omega_{t}\right]$, the explanatory variables and the error term become correlated. In order to solve this orthogonality problem, we estimate with the Generalized Method of Moments, which utilizes an optimal weight matrix that accounts for the possible serial correlation in $v_{t} .{ }^{34)}$ The estimation results are summarized in Table 5.

33) The output gap is measured by the difference between industrial production and its HP filtered series.

34) We use instrument sets, which include four lags of policy rates, inflation, the output gap, and the spread between long-term and TB (3-month) rates. 


\section{Appendix 2: IV Test Results}

\section{IVs for U.S. MP shocks}

Table 6 summarizes the results of the weak IV test, for each suggested IV for U.S. MP shocks. Each row displays the $t$-value and $R^{2}$ for the first-stage least square. We find that almost all the IV candidates have strong relationships with the residual series of the MP instrument. Spot short-term rates (IV1 3) have significant explanatory power at the $95 \%$ significance level through all sample periods tested. As already shown clearly in other studies, intraday movements of Federal Fund Futures rates and Eurodollar futures rates (IV5a 5e) are significantly relevant to the MP instruments, reporting the highest $t$-values and $R^{2}$.35) The $\mathrm{BN}$ decomposed rate (IV10) also shows high relevancy while the residual from the Taylor rule estimation (IV11) shows mixed results, which are significant for the full sample but not for the subsamples.

Table 7 exhibits over-identification test results for the proposed U.S. IVs. The IV set consisting of intraday FFFRs (IV5 series) shows very low Sargan statistics, indicating that they are sufficiently orthogonal to residual series of other endogenous variables in the VAR system. Spot short-term rates (IV1 $\sim 4)$ show mixed results; through the 1980 2008 sample, the IVs cannot reject the null hypothesis that the IVs are endogenous with other residual series of other financial instruments (3-month, 3-year, and 10-year TBs) at the 5\% significance level, but through other sub-samples the null hypothesis is not rejected.

35) According to Swanson (2016), U.S. monetary shocks identified through FFFR changes must contain different factors before and after 2009 when FFR was lowered to the zero lower bound (ZLB) as shown in the table below. FFFR changes reflect forward guidance (FG) and large-scale asset purchase (LSAP) shocks during the ZLB period, but FFR changes and FG shocks in the pre-ZLB.

\begin{tabular}{l|c|c}
\hline & pre-ZLB periods & ZLB periods \\
\hline FFR changes & $\bigcirc$ & $\times$ \\
FG shocks & $\bigcirc$ & $\bigcirc$ \\
LSAP shocks & $\times$ & $\bigcirc$ \\
\hline
\end{tabular}


Table 6: Explanatory Power of Suggested IVs for U.S. MP Shocks

$\begin{array}{lccc} & 1980 \sim 2008 & 1984 \sim 2008 & 1989 \sim 2008 \\ \text { IV1 } & 1.82[0.01] & 2.84[0.03] & 2.36[0.03] \\ \text { IV2 } & 3.95[0.04] & 2.65[0.02] & -0.97[0.00] \\ \text { IV3 } & 4.04[0.05] & 5.00[0.08] & 4.89[0.10] \\ \text { IV5a } & - & - & 6.73[0.17] \\ \text { IV5b } & - & - & 6.08[0.15] \\ \text { IV5c } & - & 3.38[0.04] & 4.00[0.07] \\ \text { IV5d } & - & 3.79[0.05] & 3.67[0.06] \\ \text { IV5e } & 7.58[0.14] & 3.30[0.04] & 3.29[0.05] \\ \text { IV5f } & 2.41[0.02] & 2.59[0.02] & 2.83[0.04] \\ \text { IV10 } & 5.59[0.09] & 2.75[0.03] \\ \text { IV11 } & \text { (parentheses) of each IV in the firststage regression of the VAR }\end{array}$

Table 7: Sargan Statistics for Selected U.S. IVs

\begin{tabular}{|c|c|c|c|c|c|c|}
\hline \multirow{2}{*}{ Sample } & $1980 \sim 2008$ & \multicolumn{2}{|c|}{$1984 \sim 2008$} & \multicolumn{3}{|c|}{ 1989 2008 } \\
\hline & {$[\mathrm{IV} 1 \sim 3,10]$} & {$[\mathrm{IV} 1 \sim 3,10]$} & {$[\mathrm{IV} 5 \mathrm{c} \sim 5 \mathrm{f}]$} & {$[\mathrm{IV} 1 \sim 3,10]$} & {$[\mathrm{IV} 5 \mathrm{c} \sim 5 \mathrm{f}]$} & [IV5a 5b] \\
\hline Y & 6.75 & 2.19 & 1.79 & 5.03 & 1.29 & 3.57 \\
\hline$P$ & 2.49 & 2.29 & 0.22 & 8.07 & 0.89 & 0.39 \\
\hline$R 3 m$ & 15.90 & 3.11 & 0.06 & 0.24 & 1.73 & 2.87 \\
\hline$R 3 y$ & 15.90 & 0.84 & 1.06 & 2.67 & 6.44 & 7.57 \\
\hline R10y & 20.50 & 2.76 & 1.54 & 4.60 & 4.32 & 4.74 \\
\hline Lend & 5.10 & 2.80 & 0.79 & 3.25 & 8.28 & 1.82 \\
\hline L & 1 & 1 & 1 & 1 & 1 & 1 \\
\hline K & 4 & 4 & 4 & 4 & 4 & 2 \\
\hline$\chi_{0.99(0.95)}^{2}>K-L$ & & & $9.21(5.99)$ & & & $6.64(3.84)$ \\
\hline
\end{tabular}

Note: Reject $H_{0}$ at the $1 \%(5 \%)$ significance level if $\chi_{0.99(0.95)}^{2}>K-L$, where $K$ and $L$ are the number of IVs and endogenous variables, respectively. 


\section{IVs for SOE MP shocks}

We summarize the relevancy of IVs for each of the focal SOEs in Table 8. Above all, spot overnight rates (IV1) turn out to be the most highly relevant to the residual of the MP instruments, in line with Cochrane and Piazessi (2002). In all analyzed SOEs, IV1 is significant at the 5\% level and the explanatory power of the IV $\left(R^{2}\right)$ ranges from 0.07 to 0.23 . Short-term rates (with 3-month maturity, IV2) have a close relationship with the MP instruments that is significant at the $10 \%$ level in all SOEs. Daily innovation of overnight rates through BN decomposition (IV10) produces almost the same results as were obtained for IV1. However, the results for the remaining IVs are mixed by country: residuals from Taylor rule estimation (IV11) show significant relevancy except in the UK. Spot market rates (3-month maturity, IV3) and futures rates for fixed-income or bond instruments (IV5 7) are significantly relevant to MP shocks in Canada and the UK. Spot FX rates per US dollar (IV4) and futures rates under FX rates (IV8) or under a sovereign stock price index (IV9) offer little explanation of the portions of the MP instruments.

The evidence in Table 8 leads us to select the best combination of multiple IVs in terms of relevancy. The selected IV sets for each country and their $F$-values in the first-stage least square are displayed at the bottom row of Table 8.

Finally, in Table 9, the over-identification test results are summarized for the selected IV combinations for both the focal SOEs and U.S. MP shocks. At the $5 \%$ significance level, almost none of the residual series rejects the null hypothesis. This indicates that the selected IV combinations for each country are exogenous to residual series of other variables. 
Table 8: Explanatory Power of SOE IVs on the First-stage Residual of MP Shock

\begin{tabular}{|c|c|c|c|c|}
\hline & Australia & Canada & Korea & U.K. \\
\hline \multirow[t]{2}{*}{ IV1 } & 3.47 & 7.66 & 5.78 & 4.71 \\
\hline & {$[0.14]$} & {$[0.23]$} & {$[0.19]$} & {$[0.11]$} \\
\hline \multirow[t]{2}{*}{2} & 1.90 & 5.39 & 3.59 & 5.85 \\
\hline & {$[0.05]$} & {$[0.13]$} & {$[0.08]$} & {$[0.17]$} \\
\hline \multirow[t]{2}{*}{3} & 1.44 & 6.88 & -2.25 & 4.56 \\
\hline & [0.03] & {$[0.20]$} & [0.03] & {$[0.11]$} \\
\hline \multirow[t]{2}{*}{4} & 0.60 & 1.73 & 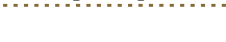 & 1.42 \\
\hline & {$[0.00]$} & {$[0.02]$} & - & {$[0.01]$} \\
\hline \multirow[t]{2}{*}{5} & -1.59 & -10.70 & & -7.38 \\
\hline & {$[0.03]$} & {$[0.37]$} & - & {$[0.24]$} \\
\hline \multirow[t]{2}{*}{6} & -0.26 & . & 1.13 & . \\
\hline & {$[0.00]$} & - & {$[0.01]$} & - \\
\hline \multirow[t]{2}{*}{7} & -0.12 & -2.69 & 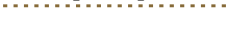 & -0.62 \\
\hline & {$[0.00]$} & {$[0.04]$} & - & {$[0.00]$} \\
\hline \multirow[t]{2}{*}{8} & 0.40 & 1.94 & -1.47 & 1.86 \\
\hline & {$[0.00]$} & {$[0.02]$} & {$[0.01]$} & {$[0.02]$} \\
\hline \multirow[t]{2}{*}{9} & an........ & -1.53 & -0.76 & 0.18 \\
\hline & & {$[0.01]$} & {$[0.00]$} & {$[0.00]$} \\
\hline \multirow[t]{2}{*}{10} & 4.12 & 7.66 & 5.71 & -4.71 \\
\hline & {$[0.18]$} & {$[0.23]$} & {$[0.18]$} & {$[0.11]$} \\
\hline \multirow[t]{2}{*}{11} & 2.09 & 2.50 & 2.73 & 0.21 \\
\hline & {$[0.06]$} & {$[0.03]$} & {$[0.05]$} & {$[0.00]$} \\
\hline IV com- & [IIV1,5, 10,11] & {$[\mathrm{IV}$ 1,2,11] } & {$[\mathrm{IV} 1,8,10,11]$} & [IV1,2,3,5] \\
\hline binations & (F-value 7.4$)$ & $(F$-value 34.6$)$ & ( $F$-value 14.3$)$ & (F-value 23.7$)$ \\
\hline
\end{tabular}

Notes: 1) $t$-values and $R^{2}$ (parentheses) of each IV in the first-stage regression of the VAR residual of MP and each IV.

2) '-' indicates that the selected IV is not available for a given sample period.

3) Bold results are significant at the $95 \%$ confidence level.

Table 9: Over-identification Test Results for Selected IVs

\begin{tabular}{|c|c|c|c|c|}
\hline Residuals & Australia & Canada & Korea & UK \\
\hline$Y$ & 6.70 & 9.68 & 9.70 & 2.19 \\
\hline$P$ & 4.83 & 7.95 & 5.77 & 5.40 \\
\hline$R 3 m$ & 1.49 & 4.41 & 4.13 & 8.77 \\
\hline R3y & 3.83 & 11.66 & 6.99 & 5.90 \\
\hline R10y & 3.37 & 10.89 & 7.98 & 3.86 \\
\hline$\angle E N D$ & 2.71 & 1.05 & 14.33 & 0.13 \\
\hline$F X$ & 5.62 & 15.75 & 25.13 & 6.83 \\
\hline K & 9 & 8 & 9 & 9 \\
\hline$L$ & 1 & 1 & 1 & 1 \\
\hline$\chi_{0.99(0.95)}^{2}>K-L$ & 15.5 & 14.1 & 15.5 & 15.5 \\
\hline
\end{tabular}

Note: Reject $H_{0}$ at the $1 \%(5 \%)$ significance level if $\chi_{0.99(0.95)}^{2}>K-L$, where $K$ and $L$ are the number of IVs and endogenous variables. 


\section{$<$ Abstract in Korean > \\ 소규모 개방경제에서의 통화정책 식별에 관한 연구}

하종림*, 소인환**

본고는 미국과 대표적 소규모 개방경제국들의 통화정책 파급 특성을 외부도 구식별법(external instrument identification)을 이용한 구조적 벡터자기회귀 모형 추정을 통해 살펴보았다. 본고는 미 연방기금금리 선물 데이터를 이용하여 미국 통화정책 효과를 분석한 기존 연구와 달리 분석대상국에 대한 대안적인 외 부 도구변수들을 활용하였다. 실증분석 결과, 미국의 통화충격은 소규모 개방 경제국 통화정책의 금융시장을 통한 파급효과를 약화시키는 것으로 분석되었다. 또한, 통화충격에 대해 환율은 Dornbusch (1976)의 오버슈팅(overshooting) 가설 에서와 같이 반응하는 것으로 나타났다.

핵심 주제어: 통화정책 파급, 외부도구식별법, 구조적 벡터자귀회귀 모형 JEL Classification: E44, E52

* 세계은행 Development Economics Prospects Group (DECPG) Economist (E-mail: jongrim.ha@gmail.com) ** 한국은행 경제연구원 금융통화연구실 부연구위원 (전화: 02-759-5413, E-mail: ihsoh@bok.or.kr)

본 연구내용은 집필자의 개인의견이며 한국은행의 공식견해와는 무관합니다. 따라서 본 논문의 내용을 보도하거나 인용할 경우에는 집필자 명을 반드시 명시하여 주시기 바랍니다. 


\section{$\mathrm{BOK}$ 경제연구 발간목록}

한국은행 경제연구원에서는 Working Paper인 『BOK 경제연구』를 수시로 발간하고 있습니다. ${ }^{\circledR B O K}$ 경제연구』는 주요 경제 현상 및 정책 효과에 대한 직관적 설명 뿐 아니라 깊이 있는 이론 또는 실증 분석을 제공함으로써 엄밀한 논증에 초점을 두는 학술논문 형태의 연구이며 한국은행 직원 및 한국은행 연구용역사업의 연구 결과물이 수록되고 있습니다.

${ }^{『} \mathrm{BOK}$ 경제연구』는 한국은행 경제연구원 홈페이지(http://imer.bok.or.kr)에서 다운로드하여 보실 수 있습니다.

제2014-1 Network Indicators for Monitoring Intraday Liquidity in BOK-Wire+

2 중소기업에 대한 신용정책 효과

3 경제충격 효과의 산업간 공행성 분석

4 서비스업 발전을 통한 내외수 균형성장: 기대효과 및 리스크

5 Cross-country-heterogeneous and Time-varying Effects of Unconventional Monetary Policies in AEs on Portfolio Inflows to EMEs

6 인터넷뱅킹, 결제성예금 및 은행 수익성과의 관계 분석

7 Dissecting Foreign Bank Lending Behavior During the 2008-2009 Crisis

8 The Impact of Foreign Banks on Monetary Policy Transmission during the Global Financial Crisis of 2008-2009: Evidence from Korea

9 Welfare Cost of Business Cycles in Economies with Individual Consumption Risk

10 Investor Trading Behavior Around the Time of Geopolitical Risk Events: Evidence from South Korea

11 Imported-Inputs Channel of Exchange Rate Pass-Through: Evidence from Korean Firm-Level Pricing Survey
Seungjin Baek •

Kimmo Soram ki • Jaeho Yoon

정호성·임호성

황선웅·민성환 ·

신동현 · 김기호

김승원 · 황광명

Kyoungsoo Yoon •

Christophe Hurlin

이동규·전봉걸

Moon Jung Choi •

Eva Gutierrez •

Maria Soledad Martinez Peria

Bang Nam Jeon •

Hosung Lim • Ji Wu

Martin Ellison •

Thomas J. Sargent

Young Han Kim • Hosung Jung

Jae Bin Ahn •

Chang-Gui Park 


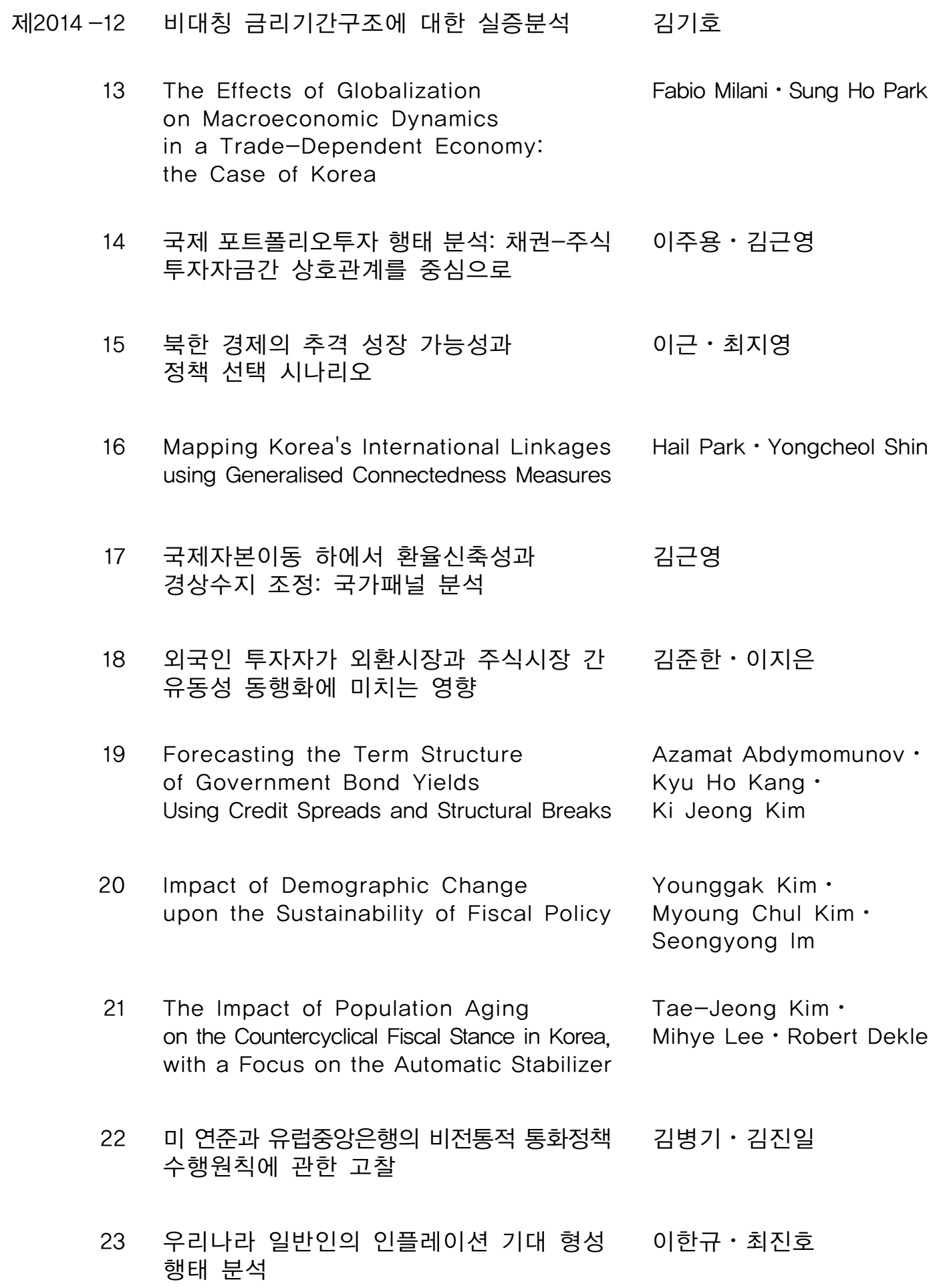

22 미 연준과 유럽중앙은행의 비전통적 통화정책 수행원칙에 관한 고찰

23 우리나라 일반인의 인플레이션 기대 형성 행태 분석

Fabio Milani · Sung Ho Park

이주용·김근영

이근 · 최지영

Hail Park $\cdot$ Yongcheol Shin

김근영

김준한·이지은

Azamat Abdymomunov . Kyu Ho Kang •

$\mathrm{Ki}$ Jeong Kim

Younggak Kim $\cdot$

Myoung Chul Kim.

Seongyong Im

Tae-Jeong Kim •

Mihye Lee $\cdot$ Robert Dekle

김병기·김진일

이한규-최진호 


\section{제2014-24 Nonlinearity in Nexus between Working Hours and Productivity \\ Strategies for Reforming Korea's Labor Market to Foster Growth}

글로벌 금융위기 이후 성장잠재력 확충: 2014 한국은행 국제컨퍼런스 결과보고서

인구구조 변화가 경제성장률에 미치는 영향: 자본이동의 역할에 대한 논의를 중심으로

\section{Safe Assets}

확장된 실업지표를 이용한

우리나라 노동시장에서의 이력현상 분석

Entropy of Global Financial Linkages

International Currencies Past, Present and Future: Two Views from Economic History

금융체제 이행 및 통합 사례:

남북한 금융통합에 대한 시사점

Measuring Price-Level Uncertainty and Instability in the U.S., 1850-2012

고용보호제도가 노동시장 이원화

및 노동생산성에 미치는 영향

해외충격시 외화예금의 역할 : 주요 신흥국 신용스프레드에 미치는 영향을 중심으로

실업률을 고려한 최적 통화정책 분석

우리나라 무역거래의 결제통화 결정요인 분석

Global Liquidity Transmission to

Emerging Market Economies, and Their Policy Responses
Dongyeol Lee $\cdot$

Hyunjoon Lim

Mai Dao - Davide Furceri -

Jisoo Hwang .

Meeyeon Kim •

Tae-Jeong Kim

한국은행 경제연구원

손종칠

Robert J. Barro

김현학·황광명

Daeyup Lee

Barry Eichengreen

김병연

Timothy Cogley •

Thomas J. Sargent

김승원

정호성·우준명

김인수·이명수

황광명 · 김경민 ·

노충식·김미진

Woon Gyu Choi ·

Taesu Kang •

Geun-Young Kim •

Byongju Lee 
제2015-1 글로벌 금융위기 이후 주요국

통화정책 운영체계의 변화

2 미국 장기시장금리 변동이 우리나라 금리기간구조에 미치는 영향 분석 및 정책적 시사점

3 직간접 무역연계성을 통한 해외충격의 우리나라 수출입 파급효과 분석

4 통화정책 효과의 지역적 차이

5 수입중간재의 비용효과를 고려한 환율변동과 수출가격 간의 관계

6 중앙은행의 정책금리 발표가 주식시장 유동성에 미치는 영향

7 은행 건전성지표의 변동요인과 거시건전성 규제의 영향

8 Price Discovery and Foreign Participation in The Republic of Korea's Government Bond Futures and Cash Markets

9 규제가 노동생산성에 미치는 영향: 한국의 산업패널 자료를 이용한 실증분석

10 인구 고령화와 정년연장 연구 (세대 간 중첩모형(OLG)을 이용한 정량 분석)

11 예측조합 및 밀도함수에 의한 소비자물가 상승률 전망

인플레이션 동학과 통화정책

Failure Risk and the Cross-Section of Hedge Fund Returns

Global Liquidity and Commodity Prices

15
Foreign Ownership, Legal System and Stock Market Liquidity
김병기·김인수

강규호·오형석

최문정·김근영

김기호

김경민

이지은

강종구

Jaehun Choi · Hosung Lim •

Rogelio Jr. Mercado •

Cyn-Young Park

이동렬·최종일·이종한

홍재화·강태수

김현학

우준명

Jung-Min Kim

Hyunju Kang •

Bok-Keun $\mathrm{Yu}$.

Jongmin $\mathrm{Yu}$

Jieun Lee $\cdot$ Kee H. Chung 


\begin{tabular}{|c|c|c|}
\hline 제2015-16 & $\begin{array}{l}\text { 바젤 III 은행 경기대응완충자본 규제의 } \\
\text { 기준지표에 대한 연구 }\end{array}$ & 서현덕·이정연 \\
\hline 17 & 우리나라 대출 수요와 공급의 변동요인 분석 & 강종구·임호성 \\
\hline 18 & 북한 인구구조의 변화 추이와 시사점 & 최지영 \\
\hline 19 & $\begin{array}{l}\text { Entry of Non-financial Firms and Competition } \\
\text { in the Retail Payments Market }\end{array}$ & Jooyong Jun \\
\hline 20 & $\begin{array}{l}\text { Monetary Policy Regime Change } \\
\text { and Regional Inflation Dynamics: } \\
\text { Looking through the Lens of } \\
\text { Sector-Level Data for Korea }\end{array}$ & $\begin{array}{l}\text { Chi-Young Choi } \\
\text { Joo Yong Lee } \\
\text { Roisin O'Sullivan }\end{array}$ \\
\hline 21 & $\begin{array}{l}\text { Costs of Foreign Capital Flows } \\
\text { in Emerging Market Economies: } \\
\text { Unexpected Economic Growth } \\
\text { and Increased Financial Market Volatility }\end{array}$ & $\begin{array}{l}\text { Kyoungsoo Yoon. } \\
\text { Jayoung Kim }\end{array}$ \\
\hline 22 & $\begin{array}{l}\text { 글로벌 금리 정상화와 통화정책 과제: } \\
\text { 2015년 한국은행 국제컨퍼런스 결과보고서 }\end{array}$ & 한국은행 경제연구원 \\
\hline 23 & $\begin{array}{l}\text { The Effects of Global Liquidity } \\
\text { on Global Imbalances }\end{array}$ & $\begin{array}{l}\text { Marie-Louise DJIGBENOU-KRE · } \\
\text { Hail Park }\end{array}$ \\
\hline 24 & 실물경기를 고려한 내재 유동성 측정 & 우준명·이지은 \\
\hline 25 & Deflation and Monetary Policy & Barry Eichengreen \\
\hline 26 & $\begin{array}{l}\text { Macroeconomic Shocks } \\
\text { and Dynamics of Labor Markets in Korea }\end{array}$ & $\begin{array}{l}\text { Tae Bong Kim } \cdot \\
\text { Hangyu Lee }\end{array}$ \\
\hline 27 & $\begin{array}{l}\text { Reference Rates and Monetary Policy } \\
\text { Effectiveness in Korea }\end{array}$ & $\begin{array}{l}\text { Heung Soon Jung } \\
\text { Dong Jin Lee } \\
\text { Tae Hyo Gwon. } \\
\text { Se Jin Yun }\end{array}$ \\
\hline 28 & Energy Efficiency and Firm Growth & $\begin{array}{l}\text { Bongseok Choi } \\
\text { Wooyoung Park } \\
\text { Bok-Keun Yu }\end{array}$ \\
\hline 29 & $\begin{array}{l}\text { An Analysis of Trade Patterns } \\
\text { in East Asia and the Effects of } \\
\text { the Real Exchange Rate Movements }\end{array}$ & $\begin{array}{l}\text { Moon Jung Choi } \\
\text { Geun-Young Kim } \\
\text { Joo Yong Lee }\end{array}$ \\
\hline 30 & $\begin{array}{l}\text { Forecasting Financial Stress Indices in } \\
\text { Korea: A Factor Model Approach }\end{array}$ & $\begin{array}{l}\text { Hyeongwoo Kim } \\
\text { Hyun Hak Kim• } \\
\text { Wen Shi }\end{array}$ \\
\hline
\end{tabular}


제2016-1 The Spillover Effects of U.S. Monetary Policy on Emerging Market Economies: Breaks, Asymmetries and Fundamentals

2 Pass-Through of Imported Input Prices to Domestic Producer Prices: Evidence from Sector-Level Data

3 Spillovers from U.S. Unconventional Monetary Policy and Its Normalization to Emerging Markets: A Capital Flow Perspective

4 Stock Returns and Mutual Fund Flows in the Korean Financial Market:

A System Approach

5 정책금리 변동이 성별·세대별 고용률에 미치는 영향

6 From Firm-level Imports to Aggregate Productivity: Evidence from Korean Manufacturing Firms Data

7 자유무역협정(FTA)이 한국 기업의 기업내 무역에 미친 효과

8 The Relation Between Monetary and Macroprudential Policy

9 조세피난처 투자자가 투자 기업 및 주식 시장에 미치는 영향

10 주택실거래 자료를 이용한 주택부문 거시 건전성 정책 효과 분석

11 Does Intra-Regional Trade Matter in Regional Stock Markets?: New Evidence from Asia-Pacific Region

12 Liability, Information, and Anti-fraud Investment in a Layered Retail Payment Structure

Testing the Labor Market Dualism in Korea
Geun-Young Kim •

Hail Park •

Peter Tillmann

JaeBin Ahn •

Chang-Gui Park •

Chanho Park

Sangwon Suh

Byung-Soo Koo

Jaebeom Kim •

Jung-Min Kim

정성엽

JaeBin Ahn •

Moon Jung Choi

전봉걸·김은숙 · 이주용

Jong Ku Kang

정호성·김순호

정호성·이지은

Sei-Wan Kim • Moon Jung Choi

Kyoung-Soo Yoon • Jooyong Jun

Sungyup Chung •

Sunyoung Jung

최지영 비공식부문 분석 


\begin{tabular}{|c|c|c|}
\hline \multirow[t]{2}{*}{ 제2016 -15 } & $\begin{array}{l}\text { Divergent EME Responses to Global } \\
\text { and Domestic Monetary Policy Shocks }\end{array}$ & $\begin{array}{l}\text { Woon Gyu Choi } \\
\text { Byongju Lee } \\
\text { Taesu Kang } \\
\text { Geun-Young Kim }\end{array}$ \\
\hline & $\begin{array}{l}\text { Loan Rate Differences across Financial } \\
\text { Sectors: A Mechanism Design } \\
\text { Approach }\end{array}$ & $\begin{array}{l}\text { Byoung-Ki Kim. } \\
\text { Jun Gyu Min }\end{array}$ \\
\hline 17 & $\begin{array}{l}\text { 근로자의 고용형태가 임금 및 소득 분포 } \\
\text { 에 미치는 영향 }\end{array}$ & 최충·정성엽 \\
\hline 18 & Endogeneity of Inflation Target & $\begin{array}{l}\text { Soyoung Kim } \\
\text { Geunhyung Yim }\end{array}$ \\
\hline 19 & $\begin{array}{l}\text { Who are the First Users of a } \\
\text { Newly-Emerging International } \\
\text { Currency? A Demand-Side Study of } \\
\text { Chinese Renminbi Internationalization }\end{array}$ & $\begin{array}{l}\text { Hyoung-kyu Chey } \\
\text { Geun-Young Kim. } \\
\text { Dong Hyun Lee }\end{array}$ \\
\hline 20 & $\begin{array}{l}\text { 기업 취약성 지수 개발 및 기업 부실화와의 } \\
\text { 연관성 }\end{array}$ & 최영준 \\
\hline 21 & $\begin{array}{l}\text { US Interest Rate Policy Spillover and } \\
\text { International Capital Flow: Evidence } \\
\text { from Korea }\end{array}$ & $\begin{array}{l}\text { Jieun Lee } \\
\text { Jung-Min Kim } \\
\text { Jong Kook Shin }\end{array}$ \\
\hline 제2017 -1 & $\begin{array}{l}\text { 가계부채가 소비와 경제성장에 미치는 영향 } \\
\text { - 유량효과와 저량효과 분석 - }\end{array}$ & 강종구 \\
\hline 2 & $\begin{array}{l}\text { Which Monetary Shocks Matter in } \\
\text { Small Open Economies? Evidence } \\
\text { from SVARs }\end{array}$ & $\begin{array}{l}\text { Jongrim } \mathrm{Ha} \cdot \\
\text { Inhwan So }\end{array}$ \\
\hline
\end{tabular}

